\title{
Metropolitan Lures: Enlightened and Jesuit Networks, and a New Node of Science
}

\section{$1 \quad$ An Agenda for Astronomic Advance}

In January 1755, the Viennese court mathematician Johann Jakob (Giovanni Jacopo) Marinoni (1676-1755) passed away. Originally from Udine, Marinoni, whose contribution to the beginnings of astronomical observation activities in the Habsburg capital has already been mentioned briefly, ${ }^{1}$ was appointed in 1703, and from 1720 he also served as the second director of the Viennese Imperial and Royal Academy for Engineering (Wiener kaiserliche und königliche Ingenieurakademie), established in 1717 under the auspices of the Aulic War Council primarily to ensure the adequate training of military engineers. ${ }^{2}$ During his more than five-decade career in Vienna, Marinoni also played leading roles in large-scale government-run projects, from modernizing and expanding the system of fortifications around the capital to the land survey of Lombardy (the so-called "Theresan cadaster" —in fact begun long before Maria Theresa's accession). ${ }^{3}$ As a surveyor, he introduced new methods and instruments in the Habsburg lands; as an astronomer, he carried out observations (also popularized in broadsheets) and even assembled students to instruct in the small observatory in his home in central Vienna, equipped with instruments purchased from far and wide, and donated in his last will to the court. In 1745, Marinoni published a volume describing the observatory, its activities, and equipment in great detail. The book was dedicated to the empress, and recommended by its reviewers, Frölich and Franz, as a textbook. ${ }^{4}$ This was a formidable legacy in more sense than one.

1 Cf. above, Chapter 1, n. 86.

2 Madalina Veres, "Constructing Imperial Spaces: Habsburg Cartography in the Age of Enlightenment" (PhD diss., University of Pittsburgh, 2015), 58-61.

3 Carlo Capra, "The State of Milan's 'New Census," Catastro (December 2002): 129-33.

4 Johann Jakob Marinoni, De astronomica specula domestica et organico apparatu astronomico libri duo (Vienna: Kaliwoda, 1745), approbatio. The foreword also reveals that Marinoni exchanged observation results with the Jesuit observatory tower, in whose construction he acted as an advisor. For Marinoni's key biographical details and his activities as an astronomer, see Friedrich Slezák, “Johann Jakob Marinoni (1676-1755)," Donauraum 21 (1976): 195207; Pärr, Maximilian Hell, 84-89 and the literature cited there. 
Precisely at this time, in keeping with the university reforms initiated by Van Swieten, a new main building of the university was being erected upon the resolution of Maria Theresa. The plans were drafted by the court architect brought to Vienna by Francis of Lorraine, Jean-Nicolas Jadot de Ville-Issey (1710-61), while the construction work was supervised by Johann Joseph Count Trautson (1707-57), archbishop of Vienna, as "protector of the university" from $175^{2}$ onward. It was also decided to launch a chair for mechanics and astronomy, and to construct a new "public," or "Imperial and Royal Observatory," on top of the new assembly hall in the new building. This decision gave the observatory a prominent position in the city center. When finished, it would rise some 37.9 meters above street level. Ideally, it should have been even higher in order to prevent the spires of the nearby Jesuit church and even the Stephansdom from blocking the view of parts of the sky, but the fundaments of the building were not strong enough to support that. ${ }^{5}$ To begin with, Father Franz was appointed as the scientific and technical supervisor of the construction of the tower, which appears to have been mostly completed and ready to be installed with the instruments bequeathed by Marinoni by the time Hell was invited from Cluj to take charge.

Hell's appointment as court astronomer resulted from the confluence of talent, contacts, and timing. His talent in the mathematical sciences, and astronomy in particular, perhaps together with his bent for practical applications, had been demonstrated and noted in Vienna, Trnava, and Cluj. That he had already published three mathematical textbooks as well as a work of history of a kind that was frequently resorted to in almanacs must also have spoken in his favor. ${ }^{6}$ Thanks to his apparent association with Königsegg as a powerful figure in an important government office, his qualities may have already been known in courtly circles, not to speak about the leverage gained from support by the

5 Steinmayr, "Geschichte der Universitätssternwarte," 265-66. The location was far from ideal in other respects, too: the traffic of chariots on the block-paved streets caused shocks even to the more modest structure, during the summer the temperature was badly affected by the radiation of the heat that the roofs received from the Sun, while in the winter the smoke from ovens often obliterated the sight. Karl von Littrow, Die neue Sternwarte der k.k. Universität Wien (Vienna: n.p., 1874), 41. Cf. Pärr, Maximilian Hell, 101.

6 In the first non-anonymous edition of the Adjumentum memoriae (Vienna: Ghelen, 1774), preface, unpaginated, Hell claims that "since chronology and geography cannot subsist without astronomy, and history without chronology and geography is a blind matron hallucinating virtually every minute, we must confess that history is in debt to astronomy in the same measure as it is in debt to chronology and geography. Accordingly, it is the prerogative of the astronomer to treat chronological-historical subjects solidly." While this quote is missing in the earlier editions, the linking of astronomy with chronology and history appears to be commonplace. 
ubiquitous Franz. As for timing, the loss of Marinoni, who despite his advanced age may have been the obvious choice for the newly created position, opened the floor for another candidate. Hell happened to be exactly the right age and had the requisite qualifications: sufficiently young and robust, and at the same time sufficiently experienced to be entrusted with this prestigious task.

Yet, at this point, it is again noteworthy that the candidate chosen was a Jesuit: had there been a strong desire or a concerted master plan to consistently dismantle the Society's influence in Vienna, this would have been an opportunity to look elsewhere. During the late 1740 s and early 1750 , the supposedly more reform-minded Benedictines of the Habsburg monarchy, ${ }^{7}$ though certainly not on a par with the Jesuits in this regard, also became highly active in the cultivation of astronomy. In 1746-48, plans were conceived for erecting a "mathematical tower" at Kremsmünster, one of their wealthiest monasteries, at that time led by the influential abbot Alexander Fixlmillner (1686-1759). Though the construction took much longer than in the case of the new Viennese observatory, by the time it was completed in $175^{8}$ the result was a truly impressive, forty-seven-meter high structure of seven stories serving the purposes of "all kinds of natural science, astronomy as well as geo-science, seismology and meteorology."9 Several learned Benedictines well versed in mathematics and astronomy participated in the planning and the execution of the project, ${ }^{10}$ including Anselm Desing (1699-1772) and Eugen Dobler (1714-96), the latter also serving as the first director of the mathematical tower.

Kremsmünster also boasted the man who, besides Hell, has been hailed as one of the two "founders of modern astronomy in Austria."11 Placidus Fixlmillner (1721-91), after studies at the Benedictine University of Salzburg, settled for

$7 \quad$ On the "Benedictine Enlightenment," see Cornelia Faustmann, Gottfried Glassner, and Thomas Wallnig, eds., Melk in der barocken Gelehrtenrepublik: Die Brüder Pez, ihre Netzwerke und Forschungen (Melk: Stift Melk, 2014); Thomas Wallnig, "Franz Stephan Rautenstrauch (1734-1785)," in Lehner and Burson, Enlightenment and Catholicism, 209-25.

However, it may not have been ready for observations until 1760. See Rabenalt, "Astronomische Forschung," 97. For a contemporaneous account, see Placidus Fixlmillner's “Kurze Geschichte und Beschreibung der Sternwarte zu Kremsmünster (nebst drey Kupferplatten)," in Jean (Johann) III Bernoulli, Sammlung kurzer Reisebeschreibungen und anderer zur Erweiterung der Länder- und Menschenkenntniß dienender Nachrichten, Vierter Band (Berlin: Bey dem Herausgeber, 1784), 373-81.

9 Wolfschmidt, "Cultural Heritage and Architecture," 7.

10 This uniquely well-documented process is described in fascinating detail in JohannChristian Klamt, Sternwarte und Museum im Zeitalter der Aufklärung:Der Mathematische Turm zu Kremsmünster (1749-1758) (Mainz: Zabern, 1999).

11 Konradin Ferrari d'Occhieppo, "Maximilian Hell und Placidus Fixlmillner: Die Begründer der neueren Astronomie in Österreich," in Österreichische Naturforscher, Ärzte und Techniker, ed. Fritz Knoll (Vienna: Verlag der Gesellschaft für Natur und Technik, 1957), 27-31. 
the rest of his life at the monastery led by his uncle Alexander in 1745 . He succeeded Dobler as director of the observatory in 1762 , and although he produced a number of works in theology, law, and music, it was as an astronomer that Fixlmillner acquired his reputation-all the more impressive as he appears to have been largely self-taught in practical astronomy. Hell visited the Kremsmünster Abbey in September 1770, and by 1771 at the latest, Hell and Fixlmillner had initiated a scientific correspondence that was to last throughout their careers, and their collaboration also entailed Fixlmillner's publication of his astronomical observations in Hell's Ephemerides. ${ }^{12}$ However, in 1755 clearly none of these figures were a match to Hell in terms of experience and expertise in the fields indispensable for filling the new position at the University of Vienna. ${ }^{13}$ Besides good contacts close to the fire, the principles of enlightened meritocracy also favored the emerging Jesuit.

The new court astronomer was called back to his home university in September $1755^{14}$ and began his new role on November 1. A description of the position- "instruction," in German, with Latin phrases interspersed-is attached to the letter of appointment, issued by the chamber of Lower Austria on October $30,1755 \cdot{ }^{15}$ This is a very valuable document: it prescribes in great detail diverse activities, and thus expresses with exactitude the expectations harbored by his administrative and academic superiors who designed the position in the whirlwind of university reform.

12 Information on Fixlmillner's career has been gleaned from Wurzbach, Biographisches Lexikon (1858) 4:261-62 and Rabenalt, "Astronomische Forschung." See also the useful overview of Fixlmillner's life and writings in Scriptores ordinis S. Benedicti qui 1750-180o fuerunt in Imperio Austriaco-Hungarico (Vienna: Leon, 1881), 95-98.

13 It is worth mentioning that in other important instances the Viennese decision-makers did not shy away from filling a newly created, key university chair with a scholar who, to all intents and purposes, trained himself in the given field "on the job." A case in point is Joseph von Sonnenfels (1732-1817) — very much a generalist philosophe on the Viennese literary scene, best known for his advocacy of the cultivation of the German vernacular, before his appointment as professor of Polizeywissenschaft at the university in 1763 .

14 "In September of the year 1755, I was called, totally unexpected and urgently, from Cluj to the chair that I now keep here in Vienna," Hell recalled a few years later. Hell, Anleitung zum nützlichen Gebrauch der künstlichen Stahl-Magneten, 13. In his first letter to Delisle in Paris, dated Vienna, February 2, 1758 (Archives nationales, Paris, MAR/2JJ/66), Hell gives the exact date as September 14, 1755 .

15 Ernennung Maximilian Hells zum k.k. Astronomen. Beilage: Instruction. Für dem Kaiser. Königl. Astronomen Maximilianum Hell S.J. Universitätsarchiv Wien (hereafter: UAW), Universitätskonsistorium, CA 1.2.102. See the English translation of the full text below in appendix 1. Cf. Pinzger, Hell emlékezete, 16-17 (in Hungarian translation). In the letter to Delisle mentioned above (n. 14), Hell gave a succinct summary (confined to five items out of the original seven). 
To begin with, the imperial and royal astronomer was "to set in place a perfect arrangement [vollkommene Einrichtung] for all the instruments pertaining to this study [Studium] and make sure they are calibrated when necessary and well taken care of."16 Though the word Einrichtung has a wide meaning, it is a question of whether the "perfect arrangement" of the fresh heritage of Marinoni's instruments also implied their "regular perfection and modernization," as suggested in some of the literature. ${ }^{17}$ Hell himself wrote in a letter to the French astronomer Joseph-Nicolas Delisle (1688-1768) merely that he was to take good care of the instruments that were already to hand..$^{18}$ While he did acquire some instruments for his observatory over the years, this act of "modernization" was neither required of him in his work instruction, nor anything pursued as vigorously and systematically as at some other places even in Central Europe. The stock of instruments that was available to Hell ${ }^{19}$ was far from the most up-to-date available in this period. On this point, Hell was soon surpassed by, for instance, the Jesuit Christian Mayer's (1719-83) observatories in Schwetzingen (established 1761) and Mannheim (established 1772), where considerable resources were set in motion to acquire instruments from the best makers in England. ${ }^{20}$ In contrast, Hell had to make do with the heritage of Marinoni and some occasional acquisitions.

Further,

it will be [the imperial and royal astronomer's] responsibility to make daily observations of the trajectories of the planets, thereby taking heed of the astronomical journals [Ephemerides astronomicae] that were begun by, and continued through many years by the Gentleman de Marinoni, and to enter his observations meticulously in suitable notebooks. ${ }^{21}$

Apart from the fact that the fate of Marinoni's journals is unknown, and even Hell's manuscripts of observations - with the notable exception of some of his diaries from the expedition in Denmark-Norway—have not been found, while of course he did publish all kinds of astronomical observations for years to

\footnotetext{
16 Instruction. Für dem Kaiser. Königl. Astronomen Maximilianum Hell, S.J.

17 See Pinsker, "Der Astronom Pater Max Hell S.J.," 105.

18 The same letter as in $\mathrm{n} .14$ and n. 15 .

19 Hamel, Müller, and Posch, Die Geschichte der Universitätssternwarte; Aspaas, Posch, and Müller, "Astronomische Observatorien," 94-97.

20 Alexander Moutchnik, Forschung und Lehre in der zweiten Hälfte des 18. Jahrhunderts: Der Naturwissenschaftler und Universitätsprofessor Christian Mayer S.J. (1719-1783) (Augsburg: Dr. Erwin Rauner Verlag, 2006), 74-85, 257-69.

21 Instruction. Für dem Kaiser. Königl. Astronomen Maximilianum Hell S.J.
} 
come in his public Ephemerides, there is nothing especially noteworthy in this point of the instructions. More interesting is the next one, according to which "the public is to be urged and invited by way of published announcements or posters placed on gates to make observations of eclipses, occultations of stars, comets, and other unusual astronomical phenomena." ${ }^{22}$ This part of the instructions recognizes and proposes to give a further boost to the avid interest taken by European publics in celestial phenomena, especially on the rise since the invention of the telescope, and perhaps-in combination with the fifth point-also to streamline this interest. The age of the famous "UraniaSternwarten" (Urania observatories), established with the specific aim of disseminating scientific knowledge and developing a much wider outreach than the Imperial Observatory of Vienna was ever expected to have, ${ }^{23}$ was of course still a matter of the future. Nevertheless, the seventeenth- and eighteenthcentury press was swarming with reports about exactly the kinds of celestial events mentioned by the instruction, and in turn such events, together with the instruments and the practices of their observation, also appear to have become sufficiently embedded in European cultural sensibilities to provide a new semantics of objectivity, accuracy, and speed as features of journalistic work. ${ }^{24}$ Both the Wienerisches Diarium (Viennese diary) and its French counterpart, the Gazette de Vienne (Gazette of Vienna) reported about the observations of Halley's Comet in 1759, made at Hell's observatory as well as that of the Jesuit collegium. At the latter site, the future emperor Joseph II was present on at least one occasion. No other visitor is mentioned by name, nor is there any hint of an invitation for others to follow his example. ${ }^{25}$ However, throughout his career Hell regularly received less high-profile guests at the observatory, foreign diplomats and visiting students alike. His observatory was an integral part of the public space of the Austrian capital.

22 Instruction. Für dem Kaiser. Königl. Astronomen Maximilianum Hell S.J.

23 See, e.g., Gudrun Wolfschmidt, "Die Entwicklung und Verbreitung der Urania zur Popularisierung der Astronomie," in Konferenzbeiträge/Proceedings: Festkolloquium und Fachtagung 250 Jahre Universitätssternwarte Wien, ed. Maria G. Firneis and Franz Kerschbaum, Communications in Asteroseismology 149 (Vienna: Austrian Academy of Sciences Press, 2008), 92-103; Ole Molvig, "The Berlin Urania, Humboldtian Cosmology, and the Public," in The Heavens on Earth: Observatories and Astronomy in Nineteenth-Century Science and Culture, ed. David Aubin, Charlotte Bigg, and Otto Sibum (Durham, NC: Duke University Press, 2010), 325-43.

24 Eileen Reeves, Evening News: Optics, Astronomy, and Journalism in Early Modern Europe (Philadelphia: University of Pennsylvania Press, 2014).

25 Wienerisches Diarium (hereafter: WD), May 5, May 16, and June 9, 1759; Gazette de Vienne, May 5, May 9, and May 19, 1759 . 
The fourth and fifth points of the instructions are crucial to the intended functions of the university observatory and its head, and are best considered together. According to the former:

In order to promote the honor of this capital and its university, and to steer it toward the common good, the imperial and royal astronomer shall maintain a perpetual scientific correspondence [commercium litterarium] with all the famous observatories abroad, and in so doing make sure that all observations that are necessary for the advancement of geography be communicated to this observatory by the foreign ones, and that no observations of the kind that other astronomers are eager to receive, shall be neglected by him.

Next,

all supervision of the calendars [i.e., almanacs] ${ }^{26}$ is bestowed and laid upon him. This responsibility will not only consist in making sure that everything that may originate from the superstition of the ancients and the multitude, or from the unfounded astrology, on weather, medications, bloodletting, growth of plants or human accidents, shall be completely avoided: he is also to edit an astronomical calendar every year and to publish it in time. ${ }^{27}$

These requirements further elaborate on the previously formulated expectation of developing a public profile for the observatory. To begin with the aspect

26 "Calender" (or "Kalender") in early modern German is a broad designation corresponding to the English word "almanac." The German word "Almanach" is a late eighteenth-century import from French, which initially was reserved for almanacs with poems (frequently referred to as "Musen-Almanach"); cf. Hartmut Sührig, "Die Entwicklung der niedersächsischen Kalender im 17. Jahrhundert," Archiv für die Geschichte des ganzen Buchwesens 20 (1979): 329-794, esp. 335-72.

27 Instruction. Für dem Kaiser. Königl. Astronomen Maximilianum Hell S.J. Calendars had many truly useful functions like registering the dates of fairs and the schedule of postal services, or providing advice on the preservation of health in each season on the basis of centuries-old experience, and many others. But to illustrate the relevance of the polemic against divination based on astrology included in calendars with one example among many: a calendar issued in Bratislava in exactly the same year as the instruction to Hell, determined on the basis of zodiac signs the best days of the year for not only bloodletting and purging or hunting and fishing, but even cutting hair and nails. I. Gábor Kovács, Kis magyar kalendáriumtörténet 1880-ig.: A magyar kalendáriumok történeti és müvelődésszociológiai vizsgálata (Budapest: Akadémiai Kiadó, 1989), 27. 
elaborated in the fifth point, working for and especially on the public implied an educational mission that pointed beyond the discipline of astronomy and was to engage and undermine the meanings traditionally associated with celestial phenomena. The explicit injunction to level sound astronomical and other scientific knowledge against superstitious beliefs via the supervision of calendars - the practical guide of the common man for locating himself in time by an overview of the seasons, holidays, rendering or prescribing specific activities to them, marking ordinary or curious occurrences and proposing modes of relating to them-could well be understood as an attempt to enlist, perhaps even against his own inclination, the Jesuit scholar for the cause of Enlightenment. Given Van Swieten's pervasive influence and his frontal offensive against every manner of superstition, this would not be implausible, except that there was nothing particularly unpalatable in it for a loyal member of the Society of Jesus. In fact, on Hell's own testimony, the instruction for him was conceived by no other than Father Franz. ${ }^{28}$ Inasmuch as it was an Enlightenment document, the Enlightenment in question is a Jesuit one.

In any case, the first half of the 1750 s was exactly the time when the issue of superstition was put into the limelight in the Habsburg monarchy by cases of alleged "vampirism" or magia posthuma - revenants harming the living-in Serbia, the Banat, and Moravia. ${ }^{29}$ While military surgeons active in the southern frontier regions inquired into the cases in the former two provinces, court physicians were sent to investigate those in Moravia, and their reports (together with Van Swieten's advice pursuant to them) served as the basis for Maria Theresa's decision to take legal measures to stamp out "superstition." In March 1755, during the period immediately preceding the issuance of the instruction to Hell, a royal rescript forbade traditional measures against magia posthuma, which was followed by a circular letter to the parishes and courts of Hungary condemning a broader range of superstitious beliefs, including soothsaying, treasure-digging, divination, and the persecution of witches. In September, another decree prohibited the clergy from intervening in vampire cases without the approval of the secular authorities, and required consultation with medical specialists. It also ordered the translation from the original French into

28 Hell to Delisle, Vienna, February 2, $175^{8}$ (Archives nationales, Paris, MAR/2JJ/66).

29 On these cases and their impact, including Van Swieten's involvement, see Gábor Klaniczay, "Decline of Witches and Rise of Vampires in 18th-Century Habsburg Monarchy," Ethnologia Europaea 17 (1987): 165-80; Ádám Mézes, "Insecure Boundaries: Medical Experts and the Returning Dead on the Southern Habsburg Borderland" (MA thesis, Central European University, 2013); www.etd.ceu.hu/2013/mezes_adam.pdf (accessed April 15, 2019). It is perhaps worth noting that this aspect of the instructions was missing from the summary in Hell's $175^{8}$ letter to Delisle mentioned above, n. 14. 
Latin and German of a tract by Van Swieten ${ }^{30}$ that offered a fully natural explanation of the phenomena serving as a basis for vampire beliefs (such as the processes of fermentation and lack of oxygen as reasons for the slower decomposition of the body). Remarkably, before delving into the specific subject matter of vampirism, in his introduction Van Swieten presented a view of the relationship between science and religion not at all incompatible with that outlined above with reference to the Catholic Reform. ${ }^{31}$ He acknowledges the existence of miracles especially as proofs for the omnipotence of God resorted to as a means of conversion, whether in the early days of Christianity, or in modern missions. He is even willing to recognize Satan's power as real. The question is not, Van Swieten stresses, whether "extraordinary effects" have taken place, but whether they can be demonstrated to have arisen from supernatural causes. He goes on to suggest that

since the sciences and the arts have taken momentum, the natural causes of many effects that formerly left the ignorant in marvel have been clearly discovered. Take, for example, the eclipses, which threw entire peoples, for whom these appeared as miracles, into the most frightful terror and anxiety in old times. However, the improvement of astronomy has dispelled all this terror. [...] We calmly contemplate the omnipotence of the Creator, who moves these huge bodies in such an infinitely vast space with such a precision, throughout so many centuries, that even the weak human understanding has been enabled to calculate with exactitude their return at a certain time in future centuries. ${ }^{32}$

It is only the ignorant who can be deceived by charlatans and impostors into wonderment at the sight of the works of gunpowder, electricity, or optical devices, but the progress of knowledge reduces the number of genuine miracles.

Van Swieten, the apparently uncompromising promoter of rational reform, speaks here a language familiar from the program of Catholic Reform, gaining further impetus from the Enlightenment preoccupation with progress. In developing this combination, he has been shown to have relied on recent developments in Italian enlightened Catholicism, especially the works of Lodovico

30 Remarques sur le vampyrisme de Sylésie de l'an 1755, faites à S.M.I. et R.; republished as an appendix in [Andreas Ulrich Mayer], Abhandlung des Daseyns der Gespenster, nebst einem Anhange von Vampyrismus (Augsburg: n.p., 1768). In October 1756, an Italian edition appeared in Rovereto, and according to the preface of the 1768 version, it was also translated into German in February $175^{6}$.

31 Cf. above, "Introduction," 11-17.

32 Van Swieten, "Vampyrismus," in [Meyer], Abhandlung, appendix, 7-8. 
Antonio Muratori (1672-1750) and his followers like the Roveretan Girolamo Tartarotti (1706-61). ${ }^{33}$ In turn, the latter's local friend Giuseppe Valeriano Vanneti (1719-64) was the translator of the 1756 Italian edition of Van Swieten's treatise on vampirism. ${ }^{34}$ In the conceptual framing of this work, the chief strategist of Viennese academic reform employed an example to underline the reconcilability of religious belief with the enlightened pursuit of knowledge and social betterment that was derived from the discipline of the newly appointed court astronomer and resonated well with the exhortation in the instruction issued to the latter around the same time to turn the achievements of that discipline to the defeat of "superstition." Hell's appointment and the job description accommodated smoothly in the program of enlightened reform as pursued in Vienna in the mid-1750s, and that program was congenial to his profile as a Jesuit man of science.

Virtually the only trace we have of Hell's activities in his capacity as supervisor of calendars is a work of 1760 . While the Ephemerides was published in the large quarto format and in stately Latin, which was also the language of most of his learned correspondence and publications, this booklet came out in German - obviously reflecting on the fact that lesser format calendars flourished and sold by the tens of thousands each year in the vernaculars. ${ }^{35}$ As the title page reveals, Hell — speaking from the position of both a "priest of the Austrian province of the Society of Jesus" and "astronomer of the Imperial and Royal Majesties" - offers in the book "A Brief Introduction to the Paschal Celebration for the Common Lay Person, Including a Thorough Refutation of a Work that Christoph Sigismund Schumacher, Calendar Author in Dresden has Published in the Year 176o."36 Not much is known about Schumacher (1704-68),

33 Klaniczay, "Decline of Witches and Rise of Vampires," 171.

34 Franco Venturi, Settecento riformatore: Da Muratori a Beccaria (Turin: Einaudi, 1969), $379-82$.

35 See István György Tóth, "Les analphabets et les almanachs en Hongrie au XVIII e siècle," in Les lectures du peuple en Europe et dans les Amériques du XVII ${ }^{e}$ au XX ${ }^{e}$ siècle, ed. HansJürgen Lüsebrink et al. (Brussels: Editions Complexe, 2003), 127-32. A survey of the various vernacular almanacs published in the Habsburg lands during the eighteenth century would be very welcome (the lack of a separate section on almanacs in György Kókay, Geschichte des Buchhandels in Ungarn [Wiesbaden: Harrassowitz, 1990] is regrettable). On French-language almanacs issued in Habsburg lands during the eighteenth century, see Hans-Jürgen Lüsebrink and York-Gothart Mix, eds., Französische Almanachkultur im deutschen Sprachraum (1700-1815) (Göttingen: Vandenhoeck \& Ruprecht, 2013).

36 Maximiliani Hell S.J. der Oesterreichischen Provinz Priestern Ihro beyder Kaiserl. Königl. Majest. Astronomi bey der uralten hohen Wienerischen Universität Kurzer Unterricht der Oster-Feyer für den gemeinen Mann samt der gründlichen Wiederlegung einer Schrift, welche Herr Christoph Sigismund Schumacher, Calender-Schreiber in Dreßden unter der 
except that he was an astronomer noted on account of his reliable calculations by Bernoulli in his Recueil pour les astronomes (Anthology for the astronomers [1771-73]). Two letters from him to Hell, both dated Bratislava in the spring of 1759, are preserved. Schumacher there presents himself as an almanac editor and astronomer who has previously stayed in Transylvania and the eastern parts of Hungary. He has had little success so far, but is determined to linger on in Hungary until God decides otherwise. ${ }^{37}$ Soon afterward, he appears to have returned to Germany, where he had been born, and died in Leipzig in dire circumstances. As a Protestant, he is said to have "mocked" Catholics for having missed celebrating Easter on the proper date. ${ }^{38}$ While this was not "superstition," it naturally called for an academically sound defense of "Easter as it is practiced in the Roman Catholic Church," which Hell undertook in the booklet. He underscored that he wrote this text on the paschal celebration "in the truly vulgar civic mother tongue" (in der gänz gemeinen bürgerlichen Muttersprach) because he wanted to reach the "common man" (gemeine Mann). ${ }^{39}$ Latin functioned well in learned communication, but Hell was willing to switch language in order to reach the public of the calendars.

To return to the fourth point of the instruction and the final remark of the fifth one, the public aspects of the appointment appear in them in a different guise. They articulate an endeavor to strike a name for Vienna on an international plane by integrating the institution with state-of-the-art work in the field and making the imperial capital competitive in this regard - the same as the reforms of finances, the administration, the military, and so on taking place in the same period were to achieve in these respective areas. From early on, Hell indeed started to make international contacts. This can be perceived not only from the appendices of his Ephemerides, which give an idea of a rapidly expanding network, but also from entries in prestigious journals like the Nova acta eruditorum (New transactions of the learned) of Leipzig or the Journal des Sçavans (Journal of scholars) of Paris. ${ }^{40}$ What survives of Hell's letters

Innschrift Untersuchung der Oster-Feyer von Anno 1700. bis 2500. verfasset und Anno 1760. in Druk gegeben hat (Vienna: Trattner, 1760).

37 Schumacher to Hell in Vienna, dated Bratislava, March and May 1, 1759 (wUs, secretary's copy).

38 Pinzger, Hell Miksa, 1:62.

39 Hell, Kurzer Unterricht, preface, unpaginated.

40 See, e.g., Nova acta eruditorum for February 1762, 49-58; Journal des Sçavans (hereafter:JS) (October 1761): 672-75. As for the latter case, there is a copy of a letter from Hell to the editors of the journal in Paris, dated Vienna, March 18, 1761 (Universitätssternwarte Wien; hereafter: wUs ), explicitly asking for a review of the Ephemerides. 
demonstrates that scientific correspondence with all major international observatories was soon by and large established. As the case of Paris illustrates, the Ephemerides seems in most cases to have functioned as a door-opener. In the autumn of 1757, two Jesuit astronomers, the above-mentioned Christian Mayer of Heidelberg and Franz Huberti (1715-89) of Würzburg, traveled to Paris to visit its main scientific institutions. Huberti brought with him a copy of the Ephemerides to show to the astronomers of Paris, and in a letter to Hell dated October 3, 1757 he described their reaction as follows:

Upon order from my Mæcenas, His most Honorable and Eminent Princeps [i.e., the prince-bishop, Fürstbischof] of Würzburg, I have found myself under obligation to go to Paris, despite my wish to pay Vienna another visit. I showed your Ephemerides, which I had brought with me, to the astronomers of Paris. It was pleasant so see how they at first sight raised their eyebrows, but soon praised the great industry of the calculations and immediately asked me to provide a copy for them from Germany. Only Delisle, a man who is advancing his old age, very favorable to our Society and thoroughly outspoken, added that he had great respect for your calculations, but would have preferred that you spent more of your time on observations than on calculations. I answered that you would not take a rest from the task of making observations either. ${ }^{41}$

Arguably, the main achievement of Hell was indeed the Ephemerides ad meridianum Vindobonensem, the first volume of which covered the year 1757 and which continued until 1806 (published 1805). In 1760, without revision of contents or layout, it was renamed the Ephemerides astronomicae ad meridianum Vindobonensem, a name it retained until the very end. This periodical not only contained tables of the rising and setting of the Sun and other standard contents of astronomical almanacs; it also included observation data collected from an ever-widening range of locations, as well as articles and treatises on various scientific subjects as appendices. ${ }^{42}$ The significance and the trajectory of the annual will be discussed in detail below. What deserves mentioning here is that it was probably in recognition of its standards that Hell was elected corresponding member (membre correspondant) of the Académie Royale des

41 Huberti to Hell in Vienna, dated Paris, October 3, 1757 (wUs, secretary's copy). For more on the visit of Huberti and Mayer to Paris, see Moutchnik, Forschung und Lehre, 67-69; $15^{2-} 54 ; 447$.

42 For a complete list of items published in the Ephemerides, see Carlos Sommervogel, "Hell, Maximilien," in Bibliothèque de la Compagnie de Jésus [...] Bibliographie (Brussels: Oscar Schepens, 1893), 4:238-58. 
Sciences of Paris shortly after the episode related above. This was the first time that a representative of the Austrian province of the Society of Jesus had received this honor, ${ }^{43}$ also marking the start of a close and long-standingthough sometimes rather strained—scientific cooperation between the imperial astronomer of Vienna and his colleagues in France. Hell's surviving letters bear witness of a rather frequent correspondence with the major French contemporary astronomers-Nicolas-Louis de Lacaille (Abbé Lacaille [1713-62]), Joseph-Nicolas Delisle (1688-1768), Charles Messier (1730-1817), César-François Cassini de Thury (Cassini III [1714-84]), the abbé Jean Baptiste Chappe d'Auteroche (1722-69), Alexandre-Guy Pingré (1711-96), and Joseph-Jérôme Lefrançois de Lalande (1732-1807) - from the late 1750s onward. The court astronomer of Vienna never visited France personally, and he never learned French well enough to speak or write it properly. This did not hamper communication, however, as the French astronomers would tend to write their letters in their own language while Hell composed his in Latin. The same kind of bilingual communication probably took place whenever he received Frenchspeaking visitors. ${ }^{44}$ Outside the German- and French-speaking world, in the early 1760 s Hell forged contacts with colleagues at observatories in Madrid, St. Petersburg, Milan, Bologna, Florence, Padua, and Stockholm, using Latin in all cases. ${ }^{45}$ Correspondence with England (and election to membership in several other academies) came later.

43 In September 1758, astronomer Lacaille suggested Hell as a corresponding member. With support from Lacaille's colleagues Giovanni Domenico (Jean Dominique) Maraldi (170988) and Guillaume le Gentil de la Galaisière (1725-92), Hell was formally appointed a corresponding member of the Académie Royale des Sciences on December 23 of that year (Archives de l'Académie des sciences, Paris. Protocol de séances and Lettre de nomination, signé par De Fouchy; also, Weiss to Hell in Vienna, dated Trnava, December 23, $175^{8}$ [wus, secretary's copy]). According to the Connoissance des temps for 1760 (published 1759) and later editions, Hell's formal correspondent at the academy initially was Lacaille. After the latter's demise, his contacts were Delisle (1763-68) and Lalande (1769-92).

44 The first verifiable visits took place in 1761 , when Chappe d'Auteroche passed by on his way to Tobolsk in Siberia, and Cassini de Thury arrived to observe the transit of Venus from the Jesuit observatory and to initiate a joint project of cartography. Cf. Jean Chappe d'Auteroche, Voyage en Sibérie fait par ordre du Roi en 1761, ed. Madeleine Pinault Sørensen and Michel Mervaud (Oxford: Voltaire Foundation, 2004), entries from December 31, 1760 to January 8, 1761, 2:250-51; César-François Cassini de Thury, "Observation du passage de Vénus sur le Soleil, faite à Vienne en Autriche," in Histoire de l'Académie Royale des Sciences (hereafter: HARS) 1761 (published 1763), Mémoires, 409-12.

45 For a complete list of Hell's extant correspondence, see "Metadata Serving as Basis for Illustrations of Maximilian Hell's Network in the Book Maximilian Hell (1720-1792) and the Ends of Jesuit Science in Enlightenment Europe by Per Pippin Aspaas and László Kontler 
According to the sixth point of the instructions:

The above-mentioned [i.e., Hell] is given responsibility, besides mechanical, practical, and calculatorial astronomy, also for the courses in mechanics, which he shall deliver in the German vernacular at a suitable time every Sunday in the philosophical lecture hall, and illustrate by means of mechanical experiments, and he is to announce these courses by way of posters of invitation in advance. ${ }^{46}$

Hell's activity as a lecturer is in need of further study, though the reconstruction beyond what we already know from various reports may be blocked by the lack of lecture notes or a textbook by him. The assignment to teach mechanics as well as astronomy, especially the requirement of practical illustrations, once again - like in the period of his probable association with Königsegg and the imperial mining authorities, with Franz's involvement - points to a deliberate effort on the part of the Viennese reformers to exploit his Banská Štiavnica background and experience. Nevertheless, he appears to have abandoned his lectures in "popular mechanics" after only one year because his other duties proved too time-consuming. ${ }^{47} \mathrm{He}$ did, however, host individual aspiring astronomers in his apartment in order to give them instruction in practical astronomy. Some of these visitors stayed for a few weeks or months, others up to several years.

The last point of the instructions required the imperial and royal astronomer to

report every week to the director of philosophy about all his observations and scientific correspondence, and he shall inform the director, to whom he is responsible in all matters relating to his office, about his further activities, on what subject matters are to be included in his calendars and mechanics courses, and what works he is going to publish. ${ }^{48}$

(Brill Academic Publishers, 2020)," UiT Open Repository 2019, https://doi.org/10.18710/ CVW8YU.

46 Instruction. Für dem Kaiser. Königl. Astronomen Maximilianum Hell S.J.

47 Von Littrow, P. Hell's Reise nach Wardoe, 5: cf. "Maximilian Hell," in Schlichtegroll, Nekro$\log , 288-89$. See, however, also the claim that there was a "large attendance of Hell's lectures." Konradin Ferrari d'Occhieppo, "Hell, Maximilian," in Dictionary of Scientific Biography, ed. Charles Coulston Gillispie (New York: Charles Scribner's Sons, 1970-81), 6 (1972): 234 .

48 Instruction. Für dem Kaiser. Königl. Astronomen Maximilianum Hell S.J. 
One of Hell's biographers regarded this part of the instruction as "ridiculously patronizing," and attributed it to the influence of Van Swieten and Joseph von Sonnenfels (1732-1817) - by implication, to the pervasive regulatory gaze of the emerging enlightened state and its ambition of exercising unnecessary supervisory functions over an independent man of science (who in this case was a Jesuit). ${ }^{49}$ The circumstances put this in a rather different light. The director, namely the dean of the Faculty of Philosophy, to whom the periodic reports were due and Hell was answerable in general, was at this time no other than Franz, Hell's former teacher and supporter as well as-according to Hell-the author of the instruction itself. The relationship between the two men appears to have been one of a senior and a junior member of the Society of Jesus, master and disciple, probably marked not only by mutual respect but also cordiality, consolidated by this time through more than a decade-long acquaintance and collaboration on various projects. Patronage may have been involved, but the instruction is certainly not patronizing. This is not to claim that the relationship was fully smooth. Though not much is on record, it is evident from an elaborate letter addressed to the senior astronomer Delisle in Paris that Hell felt that the tasks assigned to him by Franz were slightly too demanding: "You will surely be amazed that Father Franz, who ought to know the chores of an astronomer, was able to place the burden of obeying to these instructions on the shoulders of one man alone," Hell fumed. Without any helping hands, "no assistant, no secretary, and —worst of all—without any funds," the imperial astronomer had to take care of all his tasks on his own. A final complaint put forward in the same letter was that Franz kept Marinoni's journal of observations hidden: Hell states that he had not even been given permission to inspect them. ${ }^{50}$

As to the required reporting, unfortunately it must have been taking place orally (another sign that the dean's supervisory functions over the imperial and royal astronomer were exercised in practice rather informally - true to the nature of their personal relationship), as there are no written traces of this in the Viennese University Archives. The relatively small number of documents by Hell and ones relating to him preserved there mainly concern extraordinary issues, such as the renovation of the university building including the observatory premises; the fate of books (including those on astronomy) belonging to

49 Ferenc Pinzger, "Hell Miksa (1720-1792)," in Stella Csillagászati Egyesület Almanachja 1927-re (Budapest: Királyi Magyar Egyetemi Nyomda, 1926), 177-200, here 178. In regard of especially von Sonnenfels, this is a strange assumption, as he did not come to play any significant role in Viennese academic life until the 176os. Cf. above, 94nı3.

$5^{\circ}$ Hell's letter to Delisle in Paris, dated Vienna, February 2, $175^{8}$ (Archives nationales, Paris, $\operatorname{MAR} / 2 \mathrm{JJ} / 66)$. 
the library of the Jesuit college after the suppression of the order; the fate of the room Hell abandoned in the college during the same period; and, finally, the assignment of the room in the observatory that both he and von Triesnecker used to two students of astronomy after von Triesnecker's death. ${ }^{51} \mathrm{~A}$ detailed investigation of the interactions between Hell and the administrative and scientific staff of the university is made difficult by the scarcity of material.

The appointment also entailed an annual stipend of three hundred florins, payable from the university's coffers, an income that secured comfortable circumstances. For the time being, the site of this comfort was to be the upper floors of the new university building, directly underneath the observatory, which the court astronomer shared with his assistant (referred to as the socius, bidellus, or adjunctus), a servant (famulus), and a secretary (scriba). Furthermore, his apartment had sufficient space to host a student of astronomy for shorter or longer periods. It was a common arrangement for astronomers in those days to live in the observatory building itself: given the nightly chores that went with the profession, it was simply convenient to do so. While this also meant immediate proximity to the hub of university life - and, given the building's location, to the heartbeat of Vienna as a two hundred thousandstrong urban center-an atmosphere of seclusion seems to have reigned in these upper quarters. In a letter from 1762, Hell refers to his apartment as "an almost sacred space," inhabited only by priests. ${ }^{52}$ His living quarters, at least, were not public.

\section{Science in the City and in the World: Hell and the respublica} astronomica

Perhaps the most conspicuous aspect of the instruction to Hell is the intention of enlisting the imperial and royal astronomer and the observatory under his direction to the service of putting Vienna once and for all on the map of European science. The Habsburg capital had been a luminous center of glory and representation for a long time on many accounts, but despite institutions like the university or the imperial library, the systematic pursuit of scientific

$5^{1} \quad$ UAW, Universitätskonsistorium CA 1.0.195 ; CA 1.3.117; CA 1.3.140; CA 1.3.405; CA 1.4.158. These documents have also been cataloged, with a summary, at http://scopeq.cc.univie. ac.at/Query/volltextsuche.aspx (search on "Maximilian Hell") (accessed April 15, 2019).

$5^{2}$ Hell to Károly Eszterházy, bishop of Eger, dated Vienna, August 6, 1762. Eger, Főegyházmegyei Levéltár, Archivum vetus (hereafter: FLE, AV), 2629. 
knowledge had not come to be recognized as integral to the sinews of power until the eighteenth century. ${ }^{53}$ As such, the creation of the new observatory and the appointment of a qualified, dynamic professional at its helm was part of a more comprehensive endeavor, not confined to the university reform. Vienna in the 1750 os was swarming with scholarly initiatives, some of them launched and steered directly by the government, others more or less free from its tutelage but encouraged or condoned by it, all of them aiming at helping the Habsburg capital to keep abreast with international developments.

The creation of the Oriental Academy and the Theresianum has already been mentioned. In 1754, a Botanical Garden, initially rather a hortus medicus to support the practical training of students of medicine, was also established by Maria Theresa on the advice of Van Swieten, who proudly reported on this move - together with the acquisition of a mineral collection as well as the imperial sponsorship of von Jacquin's expedition to the Caribbean-as a proof for the emerging "taste for the sciences" in Vienna to Linnaeus. ${ }^{54}$ In 1757 , the Botanical Garden was attached to the university, and - thanks to reorganization on more broadly scientific grounds and massive growth in stock-it started to flourish from 1768 under the leadership of the founder of the Viennese botanical school: von Jacquin, now transferred from the mining academy in Banská Štiavnica to the Viennese chair of botany and chemistry. Besides, plans for an academy of sciences in Vienna, ${ }^{55}$ on the agenda with fluctuating vigor ever since Leibniz (supported enthusiastically by the general and statesman Eugene of Savoy [1663-1736]) first conceived the idea of an imperial academy of sciences there in the 1710 , were renewed in this period, and a project was submitted to von Haugwitz in $175^{\circ}$ by Josef von Petrasch (1714-72). In 1746, von

53 Even then, these remained primarily associated with the growth of military capacity. Cf. William D. Godsey, The Sinews of Habsburg Power: Lower Austria in a Fiscal-Military State 1650-1820 (Oxford: Oxford University Press, 2018).

54 Klemun and Hühnel, Nikolaus Joseph Jacquin, 51-52.

55 The following summary is mainly based on the very detailed presentation of these plans in Joseph Feil, Versuche zur Gründung einer Akademie der Wissenschaften unter Maria Theresia (Vienna: Gerold, 1860), 7-44. On Leibniz's academy project, see Günther Hamann, "G.W. Leibnizens Plan einer Wiener Akademie der Wissenschaften," in Akten des II. Internationalen Leibniz-Kongresses, ed. Kurt Müller, Heinrich Schepers, and Wilhelm Totok (Wiesbaden: Franz Steiner Verlag, 1973), 205-27; Regina Stuber, "Die hannoversche Sukzession von 1714: Leibniz im Wiener Abseits?," in Leibniz, Caroline und die Folgen der englischen Sukzession, ed. Wenchao Li (Stuttgart: Franz Steiner Verlag, 2016), 31-50. It must be added that during the same period the idea of an academy as a monastic environment for shared scholarship was widely discussed among the Benedictines of Central Europe. See Thomas Wallnig, Critical Monks: The German Benedictines, 1680-1740 (Leiden: Brill, 2019), 91-101. 
Petrasch had already founded and for several years successfully managed the Societas Eruditorum Incognitorum in Terris Austriacis (Society of unknown scholars in Austrian lands), the first German scientific society of the Habsburg lands, in Olomouc (Olmütz) in Moravia. Von Petrasch's very detailed plan included elaborate statutes, set out principles about the exact composition of the future membership, stressed the need for them to enjoy freedom from censorship, and — naturally — proposed a handsome budget to be covered from the income of the academy's publishing house. While the plan was deeply inspired by the famous writer and language reformer Johann Christoph Gottsched (1700-66), the purview of the academy was not to be confined to language and literature. On the contrary: von Petrasch criticized all the famous foreign predecessors and counterparts for being too restrictive, and set a comprehensive agenda "for the improvement of the arts and the sciences, to promote the benefit and the rise of the Austrian hereditary lands." Significantly, there was a great emphasis on international integration via correspondence and the election of external members. Eventually, von Petrasch's plan shared the fate of that of Leibniz: it was shelved. While the chief of the Imperial Chamber, Count Johann Joseph Khevenhüller-Metsch (1706-76), had some concerns about its comprehensiveness (stressing the need for distinguishing "useful" sciences from "idle" ones) and the tendency for "freethinking" that von Petrasch's views on censorship implied to him, the main reason was lack of funds.

For the time being, arguably, the main instrument of the internationalization of Viennese science was the new observatory and the fulfillment by Hell of the parts of the instruction that required him to pursue a commercium litterarium (learned correspondence) and the publication of an astronomical almanac. It is worth considering the Ephemerides, and the development of Hell's correspondence and personal relationships, in conjunction with his own astronomical contributions over the first one and a half decade of his career as imperial and royal astronomer. ${ }^{56}$

The first volume of the Ephemerides ad meridianum Vindobonensem came out in $1757 .{ }^{57}$ It continued to Hell's death and beyond, under his successor von

$5^{6}$ An earlier version of the development of the Ephemerides was presented in László Kontler, "The Uses of Knowledge and the Symbolic Map of the Enlightened Monarchy of the Habsburgs: Maximilian Hell as Imperial and Royal Astronomer (1755-1792)," in Negotiating Knowledge in Early Modern Empires: A Decentered View, ed. László Kontler et al. (Basingstoke: Palgrave Macmillan, 2014), 79-105.

57 The issue for the year 1757 has no appendix, but appendices were added for every issue from the volume for 1758 onward. As to the year of printing, Hell's Ephemerides, like any other almanac, was routinely issued before the year it covered. However, the year of 
Triesnecker, until 1806. It was not only the second of modern, regularly published astronomical annuals after the Parisian Connoissance des temps (Knowledge of time) of the Bureau des Longitudes (1679), ${ }^{58}$ and preceding the London Nautical Almanac of the Commissioners of Longitudes (1767) as well as the Berlin Astronomisches Jahrbuch (Astronomical yearbook [1774]). It is also noteworthy in terms of its difference in contents and conception from each of these prestigious counterparts. Like Hell, the Jahrbuch's editor Johann Elert Bode (1747-1826), besides publishing the astronomical tables for the given year and news and treatises in the field, also aimed at reporting on astronomical observations made at various locations in and outside Germany. ${ }^{59}$ However, the

printing is missing from the title page of every issue until the volume for 1766, published "Viennæ MDCCLXV." Thus, on the title page of the first issue, we find Anni 1757, and this year is taken for granted as the year of printing in some modern studies (e.g., Ferrari d'Occhieppo, "Hell and Fixlmillner," 28; Harris, "Boscovich, the 'Boscovich Circle," 537n19; Karin Lackner et al., Der historische Buchbestand der Universitätssternwarte Wien: Ein illustrierter Katalog, vol. 2, 18. Jahrhundert [Frankfurt: Peter Lang, 2006], 17, 23). One exception to the above rule was the volume for 1761 , which was delayed due to the move of the printing house. Several items in Hell's correspondence from January and February 1761 contain apologies for this delay, revealing the exceptionality of the situation (Hell to Lacaille, to Delisle and to Messier in Paris, all dated January 31, 1761; Hell to Rieger in Madrid, dated February 6, 1761; Hell to Braun in St. Petersburg and to Chappe d'Auteroche in Tobolsk, both dated February 8, 1761; all in wus, Manuscripte Hell). Two manuscript bibliographies of Hell's published works, both written in Hell's own hand and preserved at the monastery of Pannonhalma in Hungary, explicitly state that the first volume of the Ephemerides was in fact published in $175^{6}$ (Hell's Mss "opera à P. Hell. S.J. edita" [dated June 9, 1773] and "Elenchus operum editorum à P. Maximiliano Hell” [1791]). In Hell's correspondence, no letter from the year 1756 is known to have survived. However, a letter from Stepling in Prague to Hell in Vienna, dated January 30, 1757, contains praise for the Ephemerides: "The Ephemerides published by the Reverend Father for the year 1757, which are of really high quality, I have had the great pleasure of seeing and leafing through. I congratulate you, Reverend Father, with this start, so useful for astronomy and truly honourable for Our Society [of Jesus]." All this evidence combined seems to indicate that the Anni 1757 volume was also published ahead of the year it covered.

58 In 1762 , the publication was renamed Connoissance des mouvemens célestes, a name it kept for only five years. In 1768 , it reverted back to its original name, which it retained until 1797, when the spelling Connoissance des temps was modernized into Connaissance des temps. See further Guy Boistel, "Un 'bréviaire' pour les astronomes et les marins: La Connaisance [sic] des temps et les calculateurs de Bureau des longitudes, de Lalande à Loewy (1772-1907)," Archives internationales d'histoire des sciences 64 (2014): 462-80.

59 On Bode in general, see Friedhelm Schwernin, Der Berliner Astronom: Leben und Werk von Johann Elert Bode 1747-1826 (Frankfurt: Harri Deutsch Verlag, 2006); on Bode's annuals, see Jürgen Hamel, "Ephemeriden und Informationen: Inhaltliche Untersuchung Berliner Kalender bis zu Bodes Astronomischen Jahrbuch," in 30o Jahre Astronomie in Berlin und Potsdam (Frankfurt: Harri Deutsch Verlag, 200o), 49-68; Cornelia Maria Schörg, "Die Präsenz der Wiener Universitätssternwarte und ihrer Forschungen in den deutschsprachigen 
otherwise commendable and forward-looking decision to issue the annual in German proved somewhat counterproductive from the point of view of the chances of dissemination, if we are to judge on the basis of a comment that the first volume received in the Journal des Sçavans. The author of the review rejoiced that the international "taste" for calculating the astronomical tables had resulted in a new publication, but at the end of a rather detailed account added that "we regret to see it printed in a language so little known in France, in Italy, in England, where astronomy is yet keenly cultivated."60 To a certain extent, the reviewer's words may well have been just one of the many eighteenthcentury instances of French condescension toward other languages and cultures. Still, Bode's decision to promote scientific culture in the vernacular seems to have defeated the purpose of circulation, and the work of foremost German astronomers may have continued to be noted in France and Britain despite the Astronomisches Jahrbuch. At the same time, the apparently obsolete Latin of the Viennese Ephemerides was still eligible as a lingua franca in the enlightened respublica astronomica. Besides expediency, Hell had other compelling reasons for choosing Latin. His being a member of a Catholic religious order was only one of them. As discussed in Chapter 1, Hell was also a Hungarus: a member of a caste of learned men in the multi-ethnic eastern half of the Habsburg monarchy, who, regardless of their personal ethnic background, harbored a strong sense of allegiance to the cultural traditions of the old Kingdom of Hungary, and-especially in the absence of improved vernacular languages-habitually resorted to Latin as their preferred medium of communication. ${ }^{61}$

The difference between the Ephemerides on the one hand and the Connoissance des temps and the Nautical Almanac on the other was of a different nature. The latter two confined themselves, besides the astronomical tables and the necessary commentary and explanations, to publishing (in the case of the former, relatively extensive, while in the case of the latter rather scarce) miscellaneous additional material of astronomical interest, and their maintaining

astronomischen Jahrbüchern und Fachzeitschriften 1755-1830" (Mag. Phil. diss., University of Vienna, 2009), 31-37.

6o JS (March 1775): 173 .

61 Not merely a specialty of the educated elite, Latin was even spoken by soldiers, merchants, and other ordinary people in eighteenth-century Hungary. István Tóth, Literacy and Written Culture in Early Modern Central Europe (Budapest: Central European University Press, 2000), esp. 130-45. For a comprehensive bibliography, see Gábor Almási, "Latin and the Language Question in Hungary (1700-1844): A Survey of Hungarian Secondary Literature (Parts 1 and 2)," Das achtzehnte Jahrhundert und Österreich 28 (2014): 211-319 and 30 (2016): 237-90. 
institutions published local observation results separately. By contrast, soon after its first appearance Hell's Ephemerides grew into a real switchboard for communicating information on astronomical observations carried out at an expanding - and changing - range of locations in and around Vienna, in the Habsburg monarchy, in Europe, and in the wider world. In this way, Hell uniquely shaped his almanac as a contribution to building a "total archive encompassing all celestial phenomena" not merely in chronological but also spatial terms, capturing not only the succession of stellar constellations in a given temporal unit (a calendar year) but also as many as possible of the major celestial events as observed at locations spread across the globe. ${ }^{62}$ Observation reports were already included in the second (1758) volume of the Ephemerides, published in 1757, for the time being still confined to giving an account of Hell's own activity at the university observatory in Vienna.

This remained the standard-but in an expanding number of entries and at ever-greater length - until 1761. By that year, when Hell also published in the Ephemerides a detailed forecast of and instructions for the "singular phenomenon" of the transit of Venus before the Sun expected for June 5 , the size of the appendix containing the observation reports grew threefold (thirty entries and ninety-two pages - compared to ten entries and twenty-eight pages in 1758). It also included accounts of work by others in Vienna: the "Abbé Lysogorski," and the amateur astronomer "Mr. Caspar Sambach, a painter of this famous city" who carried out observations ("instructed in my method, explained slightly earlier to him") on the top of his own house in the suburb of Spittelberg. ${ }^{63}$ The real watershed was the 1762 volume, including a comprehensive overview of observations of the transit of Venus that took place on June 5, 1761. Transit observation data were included from France (the Paris observatories), England (Greenwich), Spain (Madrid), Italy (Bologna, Rome, Padua, Florence), Germany (Ingolstadt, Munich, Würzburg, Schwetzingen, Dillingen, Göttingen, Dresden), the Habsburg monarchy (Ljubljana [Labacum, Laibach], Trnava), Poland (Poznań [Posnania, Posen]), Sweden (Stockholm), and "Muscovy" (St. Petersburg). The data are followed by a summary table providing the names of the

62 For the notion of astronomical observations and almanacs as an "archive," see Florence Hsia, "Astronomy after the Deluge," in Science in the Archive: Pasts, Presents, Futures, ed. Lorraine Daston (Chicago: University of Chicago Press, 2017), 17-37.

63 Ephemerides anni 1761 ad meridianum Vindobonensem jussu Augustorum calculis definitae a Maximilian Hell, è S.J. caesaro-regio astronomo, et mechanices experiment: Prof. public. et ordin. (Vienna: Trattner, 1760), 178. The annals will be referred to hereafter as Hell, Ephemerides Year Covered (Year Published). Unless explicitly stated, page numbers refer to the separate pagination of the appendices, not the almanac part of each volume. On Lysogorski and Sambach, see below, 122 and 148-49. 


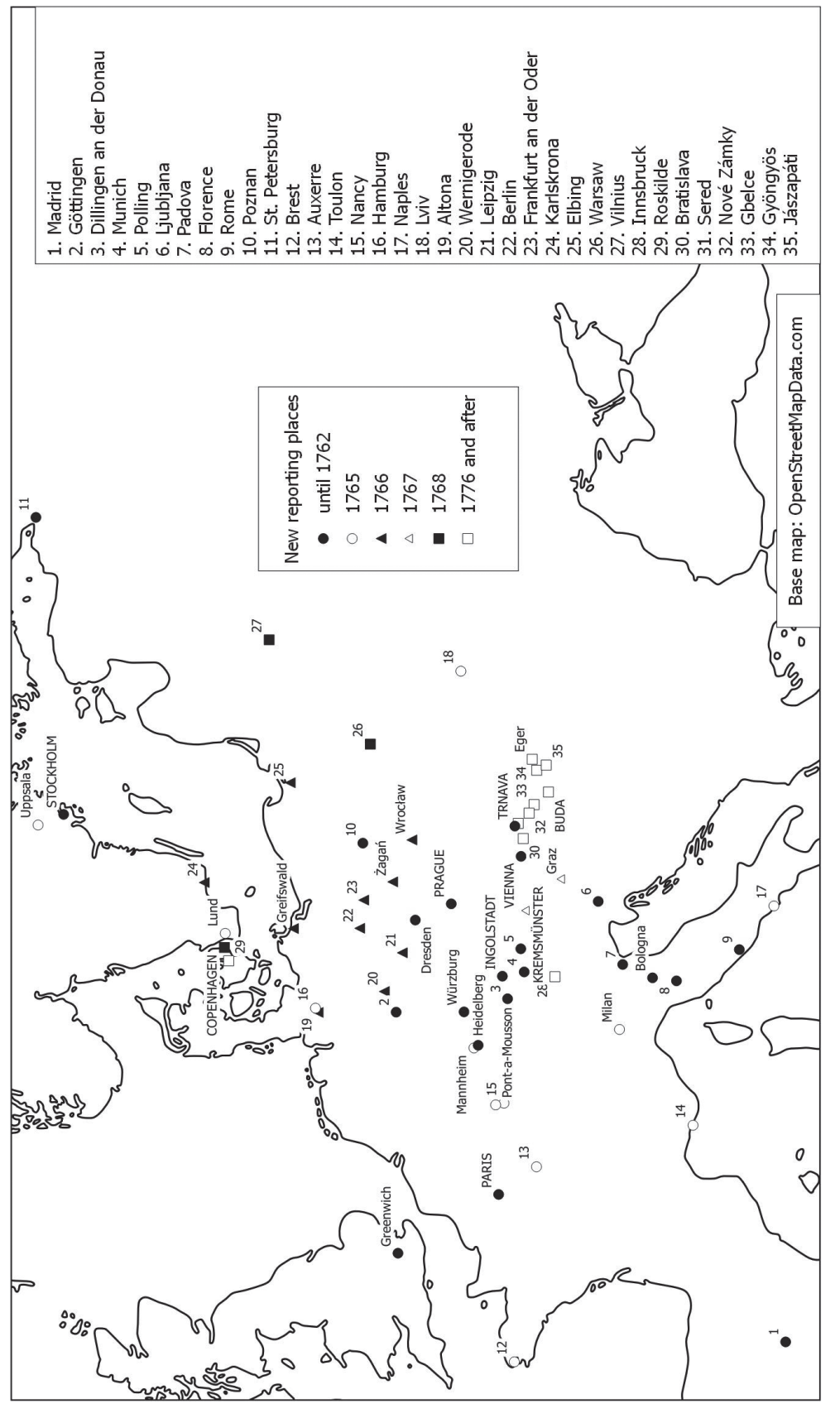

苑

๖ี

巳 t

它 芩

胥记

苍过

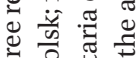

全造营

范

छ

弐

更

ฮ $\stackrel{0}{\circ}$

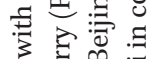

过

过艺氞

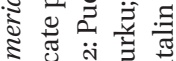

¿

요멸

巳 岂

छ छิ

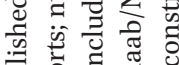

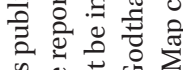

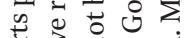

过艺

눯

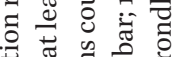

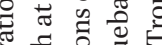

范葋

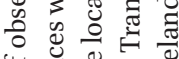

प艹

苛

荧矛

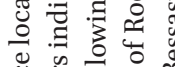

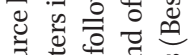

志造要

4 픈

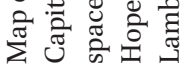

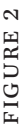


observers and the instruments used by them, and finally a collation of the data. Other astronomical observations are then reported at some length, besides places already familiar from above, also from Prague and Polling (Bavaria).

The 1763 volume neglected observations, but in 1764 the picture about the Transit enterprise was rounded off by reports on the expeditions to the Isle of Rodrigues, Tranquebar (Tharangambadi), the Cape of Good Hope, and Tobolsk-Hell not failing to note, "benevolently communicated to me by that author [i.e., the Abbé Chappe d'Auteroche]." ${ }^{\prime 4}$ Hell also published, with his own explanations, the Swedish astronomer Anders Planman's (Andreas Planmann [1724-1803]) tables of the calculations of the solar parallax by various scholars on the basis of the 1761 observations. In subsequent years, additional information source locations appeared in the appendix of the Ephemerides on astronomical observations: Uppsala, Lund, Pont-à-Mousson, Naples, Milan, Nancy, Toulon, Auxerre, Brest, Hamburg, Lviv (Lvov, Lwów, Leopolis, Lemberg) (1765); Greifswald, Finnmarchia, Blekinge, Berlin, Leipzig, Sagan, Altona, Wernigerode, Wrocław (Vratislavia, Breslau), Elblag (Elbing), Frankfurt am Oder (1766); Kremsmünster, Graz (1767); Copenhagen, Warsaw, Vilnius (1768). In 1768, Hell also published a separate set of observations from China, based on a manuscript of observations compiled by the Jesuit astronomer Augustin von Hallerstein (1703-74). In ten years from the launching of the Ephemerides, its coverage of astronomical observation activity reached continental dimensions, with a remarkable density especially in regard of the German-speaking territories. Finally, besides issuing tables of the Sun, the moon, and the planets of the solar system and widely collected observation results, supplements to the Ephemerides for the years 1763 and 1764 also contained new editions of the solar tables of Lacaille, the lunar tables of Tobias Mayer (1723-62), and the planetary tables of Cassini de Thury. These were precious items for any skilled astronomer.

The way in which the information was collected is an interesting and important question, but it is difficult to provide a conclusive answer. As a broad generalization, one may safely point to the operation of the "Jesuit network": out of the fifty-three locations from which data were collected and published in the Ephemerides between $175^{8}$ and 1768 , twenty were homes to Jesuit colleges with observatories, ${ }^{65}$ and the sources of the information from more exotic

64 Hell, Ephemerides 1764 (1763), 221.

65 Paris, Pont-à-Mousson, Rome, Bologna, Florence, Lyon, Milan, Naples, Madrid, Ingolstadt, Schwetzingen, Würzburg, Trnava, Graz, Vienna, Prague, Wrocław, Poznan, Lviv, Vilnius. To this number one may add places with Jesuit colleges that had no observatories but supplied Hell with data (such as Dillingen and Ljubljana), and two observatories maintained by other prestigious Catholic orders (Benedictines at Kremsmünster and Augustinians at 
places were also fellow brethren. Even the suppression and persecution of the Society does not seem to have initially caused a major disruption of the flow of information from such locations: observations from Pont-à-Mousson, for instance, were still reported in the Ephemerides in $1771 .^{66}$ It must also be mentioned that on the testimony of the annual, Hell was unconnected with quite a few Jesuit observatories of the time- - some of them important, others less so. ${ }^{67}$ Yet again, the absence of a location does not necessarily mean lack of connection: it suffices to mention the Mannheim of Christian Mayer. In addition, Hell's correspondence shows that he did make efforts to initiate contact with French Jesuit colleagues like Esprit Pézenas (1692-1776) in Marseille and Laurent Béraud (1702-77) in Lyon, who were not responsive.

At the same time, some of the material that fed the appendices of the Ephemerides can be traced in Hell's extant personal correspondence with the most highly recognized fellow astronomers of Europe at the time. As already seen, he was especially well connected in Paris, and Christian Mayer in Heidelberg/ Schwetzingen and Weiss in Trnava have also been mentioned. But Hell's partners also included Leonardo Ximenes (1716-86) in Florence, Eustachio Zanotti (1709-82) in Bologna, Abraham Gotthelf Kästner (1719-1800) in Göttingen, Joseph Stepling (1716-78) in Prague, Anders Johan Lexell (1740-84) in St. Petersburg, Pehr Wilhelm Wargentin $(1717-83)$ in Stockholm, and several others. ${ }^{68}$ Many of his correspondents were fellow Jesuit scholars: the strong sense of community, and the regular exchange of letters inherent in the way of life and modus operandi of the society were elements that fitted perfectly well with the

Sagan). The identification of Jesuit observatories in this note and in n. 344 is based on Udías, Searching the Heavens and the Earth, 21-22.

66 It must be added, however, that none of the recent literature known to us about the suppression of the Jesuits in the Western Catholic monarchies-such as Mélanges de 'l École française de Rome, special issue, "De la suppression à la restauration de la Compagnie de Jésus: Nouvelles recherches," ed. Pierre-Antoine Fabre, 126, no. 1 (2014), or Fabre and Patrick Goujon, Suppression et rétablissement de la Compagnie de Jésus (1773-1814) (Paris: Lessius, 2014) — discusses the question of the fate of the observatories maintained by the order. D. Gillian Thompson, "The French Jesuits 1756-1814," in Burson and Wright, Jesuit Suppression, $181-98$, discusses the fate of Jesuits, but is also silent about the impact on the Jesuit infrastructure of learning.

67 These include Lisbon, Coimbra, Avignon, Marseille, Parma, Brescia, Siena, Palermo, Mannheim, Augsburg, Olomouc (Olmütz).

68 wUs, Manuscripte Hell, vol. 3. For further analysis of the extant parts of Hell's correspondence, and the extent to which it represented a network with denominational bias, see Per Pippin Aspaas and Katalin Pataki, "Did Astronomy Constitute a Denominationally Neutral Space within the Republic of Letters? An Outline for the Use of Visualization Tools in the Study of Astronomical Correspondence," Das Achtzehnte Jahrhundert und Österreich 34 (July 2019): 65-89. 


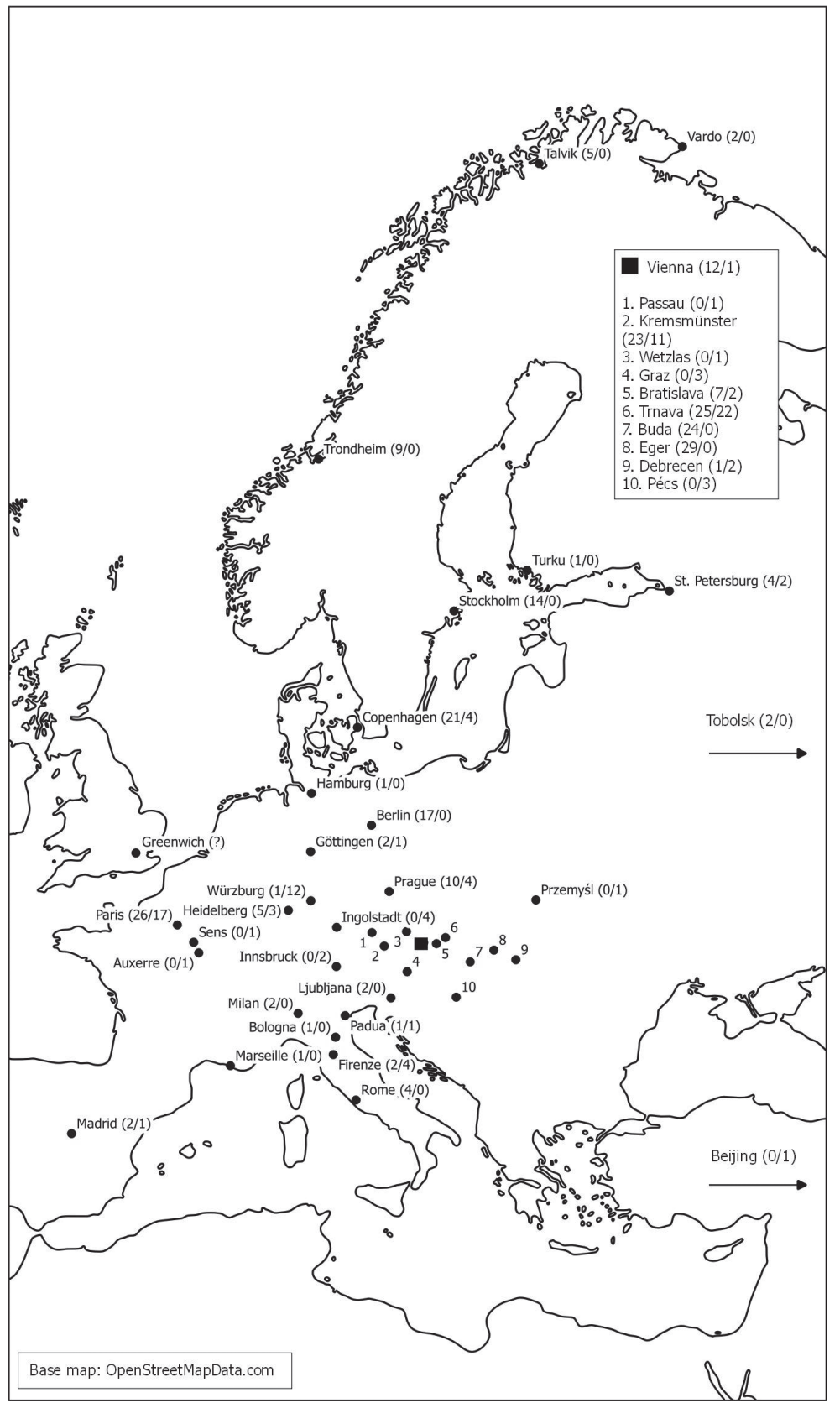

FIGURE 3 Map of Hell's correspondence (number of letters sent/received)

Only letters actually consulted by the authors have been included in the map, with the exception of Greenwich, where Hell had at least one correspondent (relevant British archives have, however, not been visited for verification). Map constructed by Katalin Pataki in collaboration with the authors 
demands of practical astronomy. ${ }^{69}$ Vis-à-vis some of these feeders of information, Hell- thanks to the means at his disposal as imperial and royal astronomer-played a role not merely as a recipient but also as a generator of information by ordering instruments from Viennese instrument-makers and distributing them to colleagues at less affluent institutions (or even amateurs) in preparation for the 1761 transit of Venus observations. ${ }^{70}$ In addition, given the time lag (in each volume, containing the astronomical tables prepared at the end of any specific year for the following year, observation reports covered the previous year-i.e., the 1767 volume published reports of observations carried out in 1765), Hell was also able to rely on published material he managed to obtain (though at least partly also thanks to the correspondence network he built). In other words, the publication activity and the maintenance of a commercium litterarium was not only combined in the instructions Hell received upon his appointment in 1755 but also in the execution of his tasks as imperial and royal astronomer. Thanks to the Ephemerides, within a decade or so from its launching, Vienna had established itself as a node of astronomical knowledge in Europe, with Hell as a nodal astronomer. Besides his expertise and (ever-more widely acknowledged) credentials as an outstanding professional, this was due to the coincidence of his being a prominent Jesuit, his prestigious position in the imperial capital, the complex character of the information contained in the publication medium, and the universal accessibility of the language chosen for its dissemination.

However, the strategy of using the Ephemerides as a tool of promotion may have served not only, and perhaps not even principally, Hell's personal advance, or the renown of Vienna and the dynasty for scientific patronage. There are reasons to believe that the Jesuit court astronomer wanted to highlight the knowledge published in the journal as "Catholic knowledge," a proof of the commitment of universal Catholicism to the cause of scientific progress, and thus to promoting the cause of enlightened reform while attenuating any antiJesuitic sentiment within it. This will be analyzed further in the next chapter, chiefly devoted to Hell's engagement with the 1761 transit of Venus. A pertinent example to be mentioned here is the enthusiastic account in the 1767 volume of the Ephemerides on the amateur scientist Peter Anich (1723-66), a simple

69 On the emphasis on correspondence in the internal structure of the Society of Jesus, see, e.g., László Szilas, "Quellen der ungarischen Kirchengeschichte aus ehemaligen Jesuitenarchiven," Ungarn-Jahrbuch: Zeitschrift für die Kunde Ungarns und verwandte Gebiete 4 (1972): 172-89.

70 See in particular the following letters: Hell to Christian Mayer, February 9, March 12, and April 10, 1761; Hell to Ximenes, February 18, 1761; cf. below, 121-2. 
farmer and turning-lathe operator from the village of Oberperfuss in Tyrol. In 1751, Anich called on the mathematics professor of the Jesuit college at Innsbruck, Ignaz Weinhart (1705-87), who, according to Hell's account, realized his visitor's talent, and decided to give him lessons on Sundays and holidays. "Thanks to his abilities and diligence," ${ }^{71}$ Anich soon became a well-trained, and in his narrow patria also well-recognized, surveyor and mapmaker. Hell corresponded with Weinhart, and their letters and their jointly written introduction to the eulogium on Anich (which also appeared separately) leave no doubt about the propagandistic goals of publishing the account. ${ }^{72}$ The authors recall the similar, also recent story of Johann Ludewig (1715-60) of Cossebaude in Saxony, whose case had been advanced as a proof that "thanks to Martin Luther, in Saxony even simple farmers cultivate philosophy, and publish works on mathematics and other sciences." ${ }^{73}$ As presented by the two Jesuit scholars, Anich is a counter-example-almost a refutation: a Catholic peasant (naturally, with proper guidance from qualified Jesuits) is at least as capable of achievement and service in the sciences as a Protestant one.

After a sketch of the build-up of the Ephemerides as a tool of obtaining international visibility, the story of Anich leads us to a consideration of the specific mechanisms and "vectors" of the operation of the Viennese university observatory as a node linking the local, metropolitan, and transnational planes or scales of pursuing astronomical and other kinds of knowledge. Hell brought to the awareness of his international peers relevant work done at a great many lesser "nodes," and representing these efforts in the Ephemerides alongside the achievements of the famous centers was very much in the spirit of the Enlightenment notions about the public and "democratic" character of scientific knowledge. This has several aspects, including cross-confessional ones. The praise lavished on Anich was undoubtedly meant to underline the excellence of the Catholic contribution to science, and Hell was-as we shall later see explicitly expressed — no great friend of Protestantism as a religious creed and

71 Hell, Ephemerides 1767 (1766), 8. Cf. the separate edition, Maximilian Hell and Ignaz Weinhart, Elogium Rustici Tyrolensis Celeberrimi Petri Anich Oberperfussensis Coloni, Tornatoris, Chalcographi, Mechanicarum Artium Magistri, Geodetce, Geographi, et Astrophili ad Prodigium Excellentis [...] (Innsbruck: Trattner, 1768), 7.

72 It might be added that a German summary of the story also appeared in the appendix of the $W D$, no. 13 (February 14, 1767) and no. 15 (February 21, 1767), unpaginated. In addition, a French resumé was published in the Parisian Journal encyclopédique; see Sommervogel, "Hell, Maximilien," 254.

73 Hell, Ephemerides 1767 (1766), 4; Hell and Weinhart, Elogium Petri Anich, 3. Cf. Johann Ludewig, Der gelehrte Bauer: Mit Christian Gotthold Hoffmanns Vorbericht nebst Kupffern (Dresden, 1756), critical edition by Holger Böning and Reinhart Siegert (Stuttgart-Bad Cannstatt: Frommann-Holzboog, 1992). 
practice. Nor was he generally of a high opinion about Protestant education and learning. Nevertheless, he was by no means averse to professional collaboration across denominational boundaries in reasonable cases, and then he cultivated a spirit of mutual collegiality. The refutation of Schumacher had confessional implications, but this was because of a perceived provocation. But Hell's apparent cooperation with the Calvinist philosophy professor in Cluj in the 1750 s had continuity in the correspondence he maintained a few years later, for instance, with the medical doctor and polymath István Hatvani $(1718-86) .^{74}$

Hatvani, a somewhat under-appreciated but remarkable figure, was a teacher of the Calvinist college of Debrecen in eastern Hungary, one of the country's most important Protestant educational institutions, established in 1538. With support from the municipal council of Debrecen and other sponsors, in the 1740 s Hatvani peregrinated to Basel, where he took degrees in theology and medicine, but as he received an invitation to return to Debrecen to teach mathematics, philosophy, and experimental physics, he also decided to study mathematics with the Bernoullis. He then spent a brief period at Leiden, taking the opportunity to work with Pieter van Musschenbroek (1692-1761), whose Elementa physicae (Elements of physics [1726]) he had already used during his studies in Debrecen. In 1748, Hatvani returned to Debrecen, despite being offered teaching positions in Heidelberg, Marburg, and Leiden. He held his inaugural lecture in January 1749 on the significance of mathematics for theology and its indispensability for physics. ${ }^{75}$ Hatvani also became a pioneer of experiments in electricity in Hungary, using an electrica machina (electrical machine)

74 On Hatvani, see Wurzbach, Biographisches Lexikon (1862), 8:49-50; József Szinnyei, Magyar írók élete és munkái (Budapest: Hornyánszky, 1896), 4; Jolán M. Zemplén, A magyarországi fizika története a XVIII. században (Budapest: Akadémiai Kiadó, 1964), 395-424; Béla Tóth, Hatvani István (Budapest: Közgazdasági és Jogi Könyvkiadó, 1977); Katalin Fehér, Hatvani István és tanítványai (Budapest: Országos Pedagógiai Könyvtár és Múzeum, 2002); Miroslav Tibor Morovics and Andrej Šperka, "The Beginnings of Scientific Interest in Electrical Phenomena in Hungarian Kingdom," in The Global and the Local: The History of Science and the Cultural Integration of Europe; Proceedings of the 2nd ICESHS, ed. Michal Kokowski (Cracow, Poland, September 6-9, 2006), 926-33; http://www.2iceshs.cyfronet. pl/2ICESHS_Proceedings/Chapter_29/R-Varia_II_Morovics_Sperka.pdf (accessed April 15, 2019).

75 The lecture was published in the journal Museum Helveticum in Zürich in 1751. According to Hatvani's interesting concept of "moral evidence," fully developed in the work mentioned below in critical engagement with Descartes, Locke, and Leibniz and strong reliance on Newton, while the fundamental task of philosophy is the quest for logical, metaphysical, and moral truth, the path to attaining the latter is not dissimilar from procedures of supplying mathematical proof, or the formation of other kinds of evidence via sense perception. 
purchased in Vienna on his way back from Leiden, others obtained later on via a Buda merchant, and ones constructed by himself. In 1757 , as a supplement to his noteworthy "introduction to the principles of a more solid philosophy,"76 he published his (very accurate) calculation of the geographic latitude of Debrecen. This is all the more noteworthy as - though in Leiden, Hatvani obtained some experience in astronomy and took part in the observation of the lunar eclipse of July 25, 1748 - Debrecen itself, like any other Protestant school in the country, was not equipped with an observatory.

Two years after his work on the latitude of his town, the professor at the reformed college contacted the Jesuit imperial astronomer. Hatvani had read in the Latin-language newspaper Diarium Viennense (Viennese diary) that Hell and his counterpart at the Jesuit observatory, Joseph Liesganig (1719-99), had recently observed Halley's Comet in the company of Emperor Francis I. Hatvani now wrote to inform the court astronomer that

on the very same day as you observed it [i.e., the comet] in the presence of His Highness the Emperor, on the 3rd of May, I too caught sight of it with my naked eye. At 9 o'clock of the same evening I showed it to our students, and at about the same time on the following evening I demonstrated it to the highly illustrious Judge of this city. ${ }^{77}$

Hatvani then proceeds to give the details of his observations, for which he used an eleven-foot telescope that Johann Friedrich Weidler (1691-1755) - a professor of mathematics and law at the Protestant University in Wittenberg, also famous for his Historia astronomiae (History of astronomy [1741]) — had once provided for him. He adds:

I am writing this to you, elevated Gentleman, for no other reason than that you shall become aware that we who live in the flatlands are not idle observers of Urania either. I beg you to forgive me, a person whom you do not know even by name, for my daring to intrude in your arduous affairs. However, it is that common bond that unites all disciplines in a sort of blood relationship, which has brought me, a man occupying the lowlands

76 István Hatvani, Introductio ad principia philosophiae solidioris cui accedit observatio elevationis poli Debrecinensis (Debrecen: Kállai, 1757), published in Hungarian as Bevezetés a szilárdabb filozófia alapelveibe (Debrecen: Debreceni Akadémiai Bizottság, 1990).

Hatvani to Hell in Vienna, dated Debrecen, May 29, 1759, wUs, secretary's copy. 
of a teacher, to dare in this letter to address you, who thanks to your great merits sits in such an illustrious chair. ${ }^{78}$

No doubt Hatvani resorted to such flowers of courtesy, not to say flattery, in order to create an opportunity to incidentally attach to his letter a copy of his printed determination of the geographical latitude of Debrecen. The imperial and royal astronomer's answer was no less swift and enthusiastic than elaborate and respectful. He congratulated Hatvani on being the first to have attempted to determine the geographical coordinates of Debrecen. What is more, Hell found Hatvani's observations sound and the calculations accurate. He even returned his interlocutor's compliments by acknowledging that Hatvani's "name, industry, and experience in the mathematical sciences have been known to me for quite a while, ever since I lived in Transylvania."79 Thus, while we cannot ascertain the extent to which Hatvani, beginning his electrical experiments in Debrecen in the 1750s, may have been aware of a similar interest on the part of Hell around the same time, the one-time Cluj professor appears to have been well informed - or found it important to pretend familiarity with Hatvani's work, which would be even more noteworthy. Moreover, in his reply Father Hell furnished Hatvani with a calculation of coming occultations of the moons of Jupiter, and encouraged him to make diligent observations of these phenomena, so that even the longitude of Debrecen could be accurately determined. In all, he promised close collaboration and ended his letter by urging Hatvani to "continue to bestow the same benevolence upon me in the future, and give more honor to the learned world as well as our homeland [Patria nostra] through the publication of your illustrious works." 80

Hatvani responded a few weeks later by assuring Hell of his determination to carry out the observations expected of him, but added that his lack of instrumentation posed serious problems. Although he was in possession of a couple of telescopes and a decent pendulum clock, he had no proper place to mount them and was even missing a quadrant. By issuing his work of astronomy, Hatvani asserted, "I wanted to set an example, so that others might discover that the Hungarians [Ungari] would not be wanting in intellectual capacity, if only they had the patrons to provide for them." 81

The exchange of letters between Hell and Hatvani appears to have stopped here, and neither the latter's comet observation nor any other future

\footnotetext{
78 Hatvani to Hell in Vienna, dated Debrecen, May 29, 1759, wus, secretary's copy.

79 Hell to Hatvani in Debrecen, dated Vienna, June 14, 1759. wUs, Hell's draft.

80 Hell to Hatvani in Debrecen, dated Vienna, June 14, 1759. wUs, Hell's draft.

81 Hatvani to Hell in Vienna, dated Debrecen, July 7, 1759. WUs, secretary's copy.
} 
astronomical activity eventually gained a mention in the Ephemerides. The episode is nonetheless interesting and important due to its conformity with the procedural and ethical norms of scientific sociability. It illustrates the attention Hell as a responsible metropolitan man of science paid to information on high-standard work done among less fortunate circumstances at more obscure locations, and the importance he attached to promptly acknowledging the value of such endeavors. Second, while Protestants remained in a precarious situation across the Habsburg possessions, the appeal to the ideals of the supra-imperial Republic of Letters ("that common bond that unites all disciplines in a sort of blood relationship") as well as to sub-imperial patriotism (Ungaria, Patria nostra) enabled the Jesuit court astronomer and the Calvinist professor from the Hungarian countryside to communicate in a mutually respectful, even cordial tone.

While there was certainly nothing marginal about Hatvani as a scholar, confessionally and geographically it is meaningful to perceive of his predicament in terms of marginality. Hell's attitude was also quite open-minded toward another sort of marginality: the contributions of enthusiastic and proficient practitioners on the margins of the profession, usually called "amateurs." 82 Despite the obvious financial and practical challenge that the procurement of proper astronomical equipment and the development of a suitable observation site implied, there were a few in Hell's network who cultivated astronomy as a matter of leisure and pleasure. At the Castle Wetzlas near Pölla in Lower Austria, for instance, the nobleman Johann Felix von Ehrmans zum Schlug (dates unknown) built an observatory in 1729, which he and his son used to observe the Venus transit of 1761. A single letter from von Ehrmans to Hell is preserved, in which the former characterizes himself as a Liebhaber der Astronomie (amateur of astronomy), and asks for advice on where to obtain solar filters for his two telescopes, a one-foot and nine-inches long Gregorian, and a four-foot long Newtonian he had ordered at the instrument-maker Schulz in Vienna. ${ }^{83}$ In the subsequently published report of the Venus transit of 1761 , Hell accords several pages to the observations of this nobleman, explaining that he had once been a pupil of the court mathematician Marinoni, from whom he had

82 The category of the scientific amateurs, with well-attested equivalents in various languages as amantes, Liebhabern, or dilettanti, has been the object of several sociological studies of the history of science; see, e.g., the special issue of Gesnerus: Swiss Journal for the History of Medicine and Sciences 73, no. 2 (2016), especially the editors' introduction: Hervé Guilleman and Nathalie Richard, "Towards a Contemporary Historiography of Amateurs in Science (18th-2oth Century)," 201-37; cf. Aspaas, Maximilianus Hell, 37-8.

83 Felix Freyherr von Ehrmans zum Schlug to Hell in Vienna, dated Wetzlas, May 8, 1761 (wus, secretary's copy). 
bought a quadrant. Hell, for his part, helped von Ehrmans with the acquisition of the Newtonian telescope. ${ }^{84}$

There were also amateurs of more modest means, such as painter Caspar Franz Sambach (1715-95), who from 1762 onward had a career as a professor and later director of the Academy of Fine Arts in Vienna. Sambach also had a reputation as an able observer. He used instruments that he himself had constructed to make observations at various locations in Vienna, and received at least verbal support from Hell. ${ }^{85}$ Hell's 1761 Venus transit report includes an account of Sambach and his observation, which regrettably failed because of clouds. Hell also mentions the observations of a Perillustris $D$ [ominus] Müller (Highly illustrious Mr. Müller) in the St. Leopold district, as well as those of a Mercator quidam (anonymous merchant) in a suburb of Vienna. ${ }^{86}$ It may also be mentioned that Sambach in 1769 provided Hell with data from a solar eclipse, which helped him determine the longitude of his observatory in Vardø. ${ }^{87}$

The Venus transit report of 1761 , along with the preserved correspondence of Maximilian Hell from the years $175^{8-61}$, lends some credibility to Hell's attempt to portray Vienna as a city where several able amantes astronomiae (amateurs of astronomy) were active. He spared no effort to assist these enthusiasts in pursuing their leisure interests. But the Vienna of the time was in the first place an emerging hub of professional astronomical research with two solid institutional bases, located within a few hundred footsteps from one another. If Hell's position as a nodal astronomer is visualized as being in the pivot of a set of concentric circles, the Viennese Jesuit observatory and its staff were certainly in the innermost of those circles.

84 Maximilian Hell, "Observatio transitus Veneris ante discum Solis die 5ta Junii 1761," in Ephemerides 1762 (1761), 62-67. Von Ehrmans's modest observatory tower still stands on top of the old castle currently used as "Ferienschloss Wetzlas"; http://www.ferienschloss. at/ (accessed April 15, 2019). In the generation after Hell, a prominent noble astronomer was Elisabeth von Matt (1762-1814). She built a private observatory in the center of Vienna and engaged in many geodetic operations in Austria and Bohemia in the early 1800 s in collaboration with Johann Tobias Bürg, adjunct at the Vienna University Observatory. See Peter Brosche and Klaralinda Ma-Kircher, "Elisabeth von Matt (1762-1814), an Enlightened Practitioner of Astronomy in Vienna," Journal of Astronomical History and Heritage 13 (2010): 187-93.

85 Steinmayr, "Geschichte der Universitätssternwarte," 282.

86 Hell, Ephemerides 1762 (1761), 20-21.

87 Maximilian Hell, Observatio transitus Veneris ante discum Solis die 3. Junii anno 1769 (Copenhagen: Giese, 1770), 33, 41. 
With a view to the proliferation of the commissions of Father Franz, in 1755$56^{88}$ there was a change at the helm of the Jesuit observatory. The successor, Joseph Liesganig89 (also spelled Liesganigg), a native of Graz, was Hell's senior by one year and entered the Society of Jesus at the tender age of fifteen. Like Hell, he pursued his university studies in Vienna, although the two men did so in almost exactly alternate years. Between 1742 and 1745, at the time when Hell took his course in philosophy and started as an assistant of Franz's, Liesganig was already back in Graz as a repetens (gymnasium teacher) of mathematics, and thereafter of rhetoric briefly in Linz. He then returned to Vienna and completed his studies in theology by 1749 (which means that in this period the two future directors had a chance to know each other: Liesganig was in his last year while Hell was in his first $\left.{ }^{90}\right)$. Liesganig later served as a preacher and the inspector at a German school in Komárno (Komárom, Komorn) along the Danube in western Hungary, and then passed his third year of probation in Banská Bystrica (probably in 1749-50, that is, two years earlier than Hell). In 1750-51, we already find him serving as a professor of mathematics in Košice, but he was back in the capital again in the following university year (when Hell had just left for his own final probation), now as a professor of mathematics at the university and assistant at the Jesuit observatory. He was thus close at hand when the court astronomer was to be appointed, but Hell — whom his connection with Franz and his overall record ${ }^{91}$ may have made a stronger candidate, despite his then current position in remote Transylvania-was preferred for that role. Liesganig had to be content with his appointment as prefect of the Jesuit observatory, a position he retained until the Society's suppression in 1773. As observatory director, Liesganig was above all given prestigious tasks in

88 Surprisingly, it cannot be fully ascertained when exactly the change took place. According to Fischer, "Jesuiten-Mathematiker in der Deutschen Assistenz," 207, Liesganig was praef[ectus] Spec[ulae] astron [omicae] in Vienna in the entire period from 1752/53 to 1772/73. According to the same source, Franz was praefectus of the observatory from $1738 / 39$ to $1754 / 55$, however. Fischer, "Jesuiten-Mathematiker," 197.

89 Already mentioned briefly above, Liesganig still awaits an academic study focusing on his life and work. The account in this section is based on Steinmayr, "Geschichte der Universitätssternwarte," 178-81; Walther Fischer, "Liesganig, Joseph," in Neue Deutsche Biographie 14 (Berlin: Duncker \& Humblot, 1985), 540-42; Fischer, "Jesuiten-Mathematiker in der Deutschen Assistenz," 207; Peter Brosche, Der Astronom der Herzogin: Leben und Werk von Franz Xaver von Zach (1754-1832) (Frankfurt: Harri Deutsch Verlag, 2009), 20-25.

$90 \quad$ Lukács, Catalogi personarum, 9:43.

91 Liesganig's only publication to date was the study tool Tabulae memoriales praecipua arithmeticae tum numericae tum literalis, geometriae, etiam curvarum, et trigonometriae, atque utriusque architecturae elementa complexae, in usum auditorum (Vienna: Trattner, 1754). 
geodesy in the entire stretch between Brno (Bruna, Brünn) in the north via Vienna and Graz to Varaždin (Varasd, Varasdinum, Warasdin) in the south, and later in life in Galicia (on both sides of the present border between Poland and Ukraine). His main work, Dimensio graduum meridiani Viennensis et Hungarici (Size of the meridian degrees of Vienna and Hungary, 1770) counts among the most important-albeit certainly not the most historiographically highlighted-eighteenth-century contributions to the determination of the shape of the Earth. ${ }^{92}$

Over the nearly twenty years that Hell and Liesganig were neighbor-directors of their observatories, they seem to have been collegial collaborators, although perhaps not close friends or confidants. ${ }^{93}$ Their relationship may best be described as one of emulation: because of the topographic conditions, if for no other reason, necessarily marked by elements of competition, but also mutual attention and respect, and a willingness to lend support to as well as learning from one another. At first, Hell, who eventually grew more famous, was not obviously the superior partner. If his appointment and the instructions to him demonstrate that he and his observatory were intended to play a crucial role in attaining objectives set by the Viennese reform-government, Liesganig's geodetic assignments were no less - in a very strict sense, in fact they were morestrategically important. Ever more accurate maps were indispensable for the purposes of the Habsburg military in the large-scale armed engagements of the middle of the eighteenth century - the War of Austrian Succession (174047) and the Seven Years' War (1756-63) — and the obtaining of in-depth knowledge of the imperial territory also served the more peaceful ends of economic governance. ${ }^{94}$ It was primarily cartographic collaboration with France as Vienna's new coalition partner-specifically, mapping the space between Paris and Vienna - after the famous reversal of alliances of 1756 that brought Cassini de Thury as the director of the Observatoire Royal to the Austrian capital in

92 See the review in JS (August 1770): 573-74; cf. Liesganig's letter to John Bevis, dated Vienna, August 4, 1767, printed in the Philosophical Transactions of the Royal Society (hereafter: PTRSL) $5^{8}$ (1768; printed 1769): 15-16. Liesganig himself conceived of his own meridian measurements as a contribution to the effort hallmarked by the activities of Charles Marie de la Condamine (1701-74) in Ecuador, Boscovich in the Papal States, and La Caille in France. See Veres, "Constructing Imperial Spaces," $365^{-66 .}$

93 Thus, among the numerous letters preserved from the expedition to Denmark-Norway, none are addressed to Liesganig. In fact, he is not even mentioned in any letter to Hell's Viennese friends during this period.

94 For a general discussion, see Wolfgang Göderle, "Modernisierung durch Vermessung? Das Wissen des modernen Staats in Zentraleuropa, circa 1760-1890," Archiv für Sozialgeschichte 57 (2017): 155-86. 
1761. ${ }^{95}$ While Hell was the first local astronomer he met there after disembarking the boat that had carried him down the Danube from Ulm, Cassini de Thury joined the observation of the famous transit of Venus before the Sun on June 5, 1761-which will be discussed in detail below—at Liesganig's observatory.

Besides his cooperation with Cassini de Thury, Liesganig was also the main Viennese contact of Boscovich, and this gives occasion to consider the relationship — or rather, the apparent lack of it—between the great Dalmatian savant and Hell. Boscovich stayed in Vienna for long periods in the late $1750 \mathrm{~s}$ and early 1760 s, and during the mid-176os he held a position as professor of mathematics at the collegium in Pavia, which was under Habsburg rule. ${ }^{96}$ It would be hard to imagine that he never met Hell. ${ }^{97}$ There are some affinities among their publications, too. In his Dissertationes quinque ad dioptricam pertinentes (Five articles on dioptrics [1767]), Boscovich presented a refutation of the existence of a moon of Venus based on similar arguments to those that Hell resorted to in his De satellite Veneris (Of the satellite of Venus), published only two years earlier. Boscovich's work was even published by the same publisher as Hell's, Trattner in Vienna (where a German translation by Scherffer also appeared in the same year). However, Boscovich makes no reference at all to the work of his confrère. ${ }^{98}$

95 See, e.g., Sven Widmalm, "Accuracy, Rhetoric, and Technology: The Paris-Greenwich Triangulation," in The Quantifying Spirit of the Eighteenth Century, ed. Tore Frängsmyr, John L. Heilbron, and Robin E. Rider (Berkeley: University of California Press, 1990), 179-206; Simone Dumont and Suzanne Débarbat, "Delisle-Cassini III: Deux pèlerins de la cartographie scientifique en Europe centrale et orientale," Revue XYZ 18, no. 67 (1996): 70-76; Moutchnik, Forschung und Lehre, 86-9o; Cassini de Thury's visit and his collaboration with Liesganig was also important for the development of cartographic projects within the Habsburg monarchy, see Veres, "Constructing Imperial Spaces," 364-80. Hell gave an account of this collaboration to Lalande in Paris, in a letter dated Vienna, June 12, 1761, reproduced in Per Pippin Aspaas, "Le père jésuite Maximilien Hell et ses relations avec Lalande," in Jérôme Lalande (1732-1807): Une trajectoire scientifique, ed. Guy Boistel, Jérôme Lamy, and Colette LeLay (Rennes: Presses universitaires de Rennes, 2010), $129-48$.

96 Boscovich visited Vienna in the period April 1757-March 1758 and again in January-May 1762. Hill, "Roger Boscovich," 47-51 and 79; cf. 79-83 on Boscovich's period in Pavia.

97 According to some of the literature, "Boscovich was in contact with Hell," a claim advanced on the ground of the parallel roles of Hell and Boscovich in the design and construction of astronomical observatories. However, no evidence is presented for such contact. Harris, "Boscovich, the 'Boscovich Circle," 538.

98 On these grounds, the monographer of the issue of the moon of Venus concludes that "there is no indication in the literature that Hell and Boscovich were in contact with one another." Kragh, Moon That Wasn't, 85. It may be of interest that Hell seems to have tried to make sure Boscovich read his book on the moon of Venus. In a fragmentary draft for a 
As for correspondence, there is a single surviving letter from Hell to Boscovich, the wording of which yields clear evidence that the two were not close collaborators. In the letter, Hell thanks Boscovich for a work sent by the latter as a present (adding, "even though this gift, a product of Your Reverence's deeply subtle intellect, was most welcome to me in itself, the most wonderful thing of all was that it made me aware that I, who had so often publicly stated my admiration for Your Reverence, was in fact kept in some sort of remembrance"); he promises to send in return to Boscovich the latest volume of the Ephemerides astronomicae, containing Hell's work on the use of Jupiter's satellites for meridian determination; he congratulates Boscovich on his appointment as professor in Pavia, and engages in other "small talk." In short, flattery and humble respect permeate the letter, not the kind of familiarity and frankness that characterize Hell's correspondence with most other colleagues. ${ }^{99}$ This single extant letter contrasts with thirty-six surviving letters addressed to Boscovich by Liesganig and thirteen by Scherffer, both Viennese Jesuits engaged in astronomy and related topics. ${ }^{100}$ It might be added that in his elaborate Aurorae borealis theoria nova (New theory on the aurora borealis [1776]), Hell refers to the theories and observations of a wide range of authors but avoids mentioning that the famous Boscovich had already treated the phenomenon in several works. ${ }^{101}$ Boscovich's silence on Hell's De satellite Veneris was thus "echoed" by Hell on that occasion.

letter apparently addressed to an Italian astronomer (internal evidence points to the second half of the year 1765 as the time of writing), Hell goes into details concerning the $D e$ satellite Veneris, adding that: "If You get the occasion to meet Father Boscovich, I am confident that he at first sight will raise a lot of objections against my point of view, for he will attempt to defend his own opinion, which is in line with that of Hugenius, but rejected by me on pages 31 and 56 . However, if he does so, I should think he will be chasing deer in the treetops." wus, Manuscripte Hell, 3 .

99 Hell to Boscovich in Pavia, dated Vienna, February 27, 1764. The letter can be traced in the online inventory of Boscovich's correspondence, published by the Commissione Scientifica Edizione Nazionale R.G. Boscovich in Milan, http://www.brera.inaf.it/boscovich/ progetto-sito/Nuovo_catalogo_lettere.doc (accessed April 15, 2019; digital copy of the letter kindly provided by Luca Guzzardi).

100 Cf. http://www.brera.inaf.it/boscovich/progetto-sito/Nuovo_catalogo_lettere.doc (accessed April 15, 2019).

101 Hell, Aurorae borealis theoria nova [...] 1776. Boscovich is known to have published works on the aurora borealis in 1738 (De aurora boreali, anonymous dissertation published twice in the same year, Rome); 1747 (Caroli Noceti e Societate Jesu: De Iride et Aurora boreali Carmina Illustrissimo ac Reverendissimo Praesuli Bernardino Giruadio dicata. Cum Notis Josephi Rogerii Boscovich ex eadem, Societate, Rome); 1748 ("Dialoghi sull'aurora boreale del P. Ruggiero Boscovich della Compagnia di Gesù lettore di matematica nel Collegio Romano," in Giornale de' letterati per l'anno 1748, 192-202, 264-75, 293-302, 239-336, 363-68; also 
Returning to the Viennese astronomic universe, besides the two observatory directors, it naturally included a good number of lesser figures, such as assistants and students. One of these at the Imperial and Royal Observatory also led Hell—after and besides his inquiries into electricity - to dip into another neighboring field of astronomy: meteorology. In various editions of the Ephemerides, meteorological reports as well as discussions of meteorological instruments were included, chiefly thanks to Hell's assistant in 1762-73, Anton Pilgram (1730-93). Pilgram - who acted as Hell's replacement in his functions, including the edition of the Ephemerides, during Hell's absence from Vienna for the Arctic expedition-later published a thick volume entitled "Investigations on What Is Probable in Meteorology" based on daily measurements made at the Imperial Observatory, as well as published observations from elsewhere in Europe. ${ }^{102}$ In 1761, upon inspection of the meteorological journals of the Jesuit observatory in Vienna, Hell himself believed that he could predict the weather for years in advance. He even wished to publish an "ephemeris of the weather" (Ephemerides meteorologicae) ahead of each year. ${ }^{103}$

When presenting this idea to Van Swieten, however, Hell was made to understand that such a publication would not receive support from the powerful councilor, who would in fact make sure it was never allowed to see the light of day. In an apparently heated conversation, Van Swieten accused Hell of having abused the title of membre correspondant by naming himself an ordinary member (Mitglied) of the Académie des Sciences, and revealed that he had spoken negatively about Hell and his meteorological theory to Her Highness (i.e., Maria Theresa). Hell's defiant reaction was to outline to Lacaille the rudiments of his theory, ${ }^{104}$ in order to make sure that, in case Van Swieten (whom

published as a separate booklet); and 1760 (Philosophiae recentioris a Benedicto Stay in Rom[ano] Archigymn[asio] eloquentiae profess[ore] versibus traditae Libri X, ad Sylvium Valentium Cardinalem amplissimum, cum adnotationibus, et supplementis P. Rogerii Josephi Boscovich S.J. in Collegio Rom [ano] publ[ico] matheseos professore tomus 2, Rome); cf. e.g. Tolomeo, Boscovich: Lettere, 13-14; and the online inventory http://www.brera.inaf.it/ boscovich/progetto-sito/opere_a_stampa.pdf (accessed April 15, 2019).

102 Anton Pilgram, Untersuchungen über das Wahrscheinliche der Wetterkunde (Vienna: Kurzboeck, 1788). On Pilgram's work, see Thomas Posch and Karin Lackner, "Anton Pilgram: Mitbegründer neuzeitlicher wissenschaftlicher Meteorologie?," in Firneis and Kerschbaum, Konferenzbeiträge/Proceedings, 55-69; Steinmayr, "Geschichte der Universitätssternwarte," 246-62.

103 Hell may have changed the name of his almanac to Ephemerides astronomicae in this year in order to differentiate it from the intended Ephemerides meteorologicae.

104 Hell to Lacaille in Paris, dated Vienna, April 27, 1761 (wUS). Further context is given in his letter to Weiss, dated Vienna, April 1, 1761 (Eötvös Loránd Tudományegyetem, Egyetemi Könyvtár [Loránd Eötvös University, University Library, Budapest—hereafter: ELTE EK], copy in Vargha priv.). The theory itself is set out in an unfinished manuscript at the wUs, 
he had until then considered a friend, he added) should steal the theory and publish it under his own name, the members of the Parisian academy would be in a position to detect this fraud and protect Hell's honor as the true inventor of the theory. Lacaille passed away less than a year later, and his correspondence soon found its way to other people's hands. This was apparently how it came about that Hell's theory circulated throughout Europe for years to come, but also without meeting much acclaim. Thus, instead of a means to protect his own honor, Hell's confident letter to Lacaille served as the exact opposite.

It is noteworthy, especially in view of later developments discussed in Chapter 7 , that several of Hell's young protégés at the observatory originated from the Hungarian part of the Habsburg monarchy. First and foremost, there was János Sajnovics, already mentioned briefly above, ${ }^{105}$ from a relatively well-todo noble family of Croat ethnic origin, but in his own words "born and raised in Hungary by Hungarian parents" in the village of Tordas near Székesfehérvár (Alba Regia, Stuhlweißenburg). ${ }^{106}$ Like Liesganig, he was merely fifteen when he entered the Society of Jesus in 1748. Having lost both of his parents by then, upon entering the Society he also relinquished the Sajnovics estate to his older brother Matthias as sole heir. He stayed in Trenčín as a novice and received his undergraduate schooling in Győr and Buda, before moving to Trnava to study at the philosophical faculty in $175^{2-54}$. One of his university teachers was György (Georg) Pray (1723-1801), who was later to become a leading historian in Hungary, and Weiss probably taught him as well. Sajnovics himself went on to teach grammar in Bratislava until 1757, when he moved to Vienna to serve as Hell's assistant (bidellus) for three years. His tasks appear to have included secretarial ones: a comparison with the handwriting of the travel diary from the

"Theoria phœnomeni ascensus, et descensus Mercurij in barometris," addressed to the Académie Royale des Sciences but possibly never submitted to Paris. However, in a letter to Röhl in Greifswald, dated Berlin, September 16, 1772, Johann Heinrich Lambert ridicules Hell's meteorological theories, which he had the opportunity to read through. See Joh. Heinrich Lamberts [...] deutscher gelehrter Briefwechsel, ed. Johann III Bernoulli, 5 vols. (Berlin: Der Herausgeber, Dessau: Buchhandlung der Gelehrten, 1781-87), 2:397-400. As late as 1786, a thirty-page long "Frank Reflections on the Meteorological Theory of Herr Hell" was issued; see Prof. Dätzl [Georg Anton Däzel], Freymüthige Gedanken über die Witterungslehre des Herrn Hells (Salzburg: Waisenhausbuchhandlung, 1786).

105 See 65, 75. For key information on Sajnovics's early career, see Emil Kisbán, Johann Sajnovics: Leben und Werk eines ungarischen Bahnbrechers und Gelehrten (Budapest: Hungária, 1943); József Erdődi, “Sajnovics, der Mensch und der Gelehrte," Acta linguistica academiae Hungaricae 20 (1970): 291-322. See also the Jesuit catalogs Austria: Catalogi breves 17631765 and $1766-1769$.

106 János Sajnovics, Demonstratio: Idioma Ungarorum et Lapponum idem esse (Copenhagen: Giese, 1770), [x]. 
1768 to 1770 Arctic expedition, also put down by Sajnovics, demonstrates that all extant transcripts of Hell's correspondence from the period 1757-59 were prepared by him. ${ }^{107}$ His service as a secretary is further corroborated in a letter of late 1758 from Weiss, asking Hell to "make sure that the parts I requested from his Ephemerides are copied by the Honorable Magister Sajnovics." ${ }^{108}$ After a brief spell of teaching in the gymnasium of Eger, (Agria, Erlau) in 1761-64 we find Sajnovics in Vienna again as a student of theology, ordained as a priest in 1763. While in these years he was not formally associated with Hell's observatory, he nevertheless took part in observations. ${ }^{109}$ Completing his third year of probation in Banská Bystrica, in 1765 he was transferred to Trnava as the assis$\operatorname{tant}$ (socius) of Weiss. ${ }^{110}$ It was from there that Sajnovics arrived back in Vienna shortly before the outset of the expedition to the Far North to resume his role as assistant of the imperial and royal astronomer.

As we shall see in detail in Chapters 6 and 8, the Arctic journey led the two men into new territories in more than one sense, and their interest in the Hungarian language, its kinship with Sámi (Lapp), and the related issue of Hungarian prehistory was of great consequence to the development of Hell's subsequent career. Besides Sajnovics, Hell extended his mentorship to other young Hungarians, forging contacts that also proved highly important in the period after the suppression of the Society of Jesus. One of these was Máté Balajthi $\left(173^{-}-?\right),{ }^{111}$ a teacher of mathematics in the town of Eger who had studied in the Jesuit schools of Györ and Košice, but in 1762 was sent to Vienna to further improve his skills under Hell's guidance by the then newly appointed bishop of Eger, Count Károly Eszterházy (1725-99).

Eszterházy was to become a contact of major importance for Hell. Educated by Jesuits in Bratislava, Trnava, and at the Collegium Germanicum et Hungaricum in Rome, the bishop was a devoted adherent of Pope Benedict XIV (16751758, r.1740-58), following him in appreciating experimental science and even the work of the philosophes. Eszterházy nevertheless remained a convinced Tridentine Catholic, opposed from the outset to Habsburg ecclesiastical

107 WUs, Manuscripte Hell. Transcripts of correspondence from the year 1760 are missing, whereas the transcripts from 1761 were made by another hand.

108 Weiss to Hell in Vienna, dated Trnava, December 23, $175^{8}$ (wUs, secretary's copy). Ephemerides might here refer to a diary, or journal of observations, not necessarily the printed Ephemerides.

109 Hell, Ephemerides 1765 (1764), 322-23.

110 In the Ephemerides of Hell, Sajnovics is mentioned among the observers in Trnava from January 1767 onward. Hell, Ephemerides 1768 (1767), 272-76.

111 Szinnyei, Magyar írók; http://mek.oszk.hu/0360o/0363o/html/b/boo707.htm (accessed April 15, 2019). 
reforms, especially in their Josephian guise. ${ }^{112}$ Already in 1762 , right after his inauguration at Eger, we find him embracing the plans of his predecessor $\mathrm{Fe}$ renc Barkóczy (1710-65) - who in 1762 was promoted to the archiepiscopal see of Esztergom - to develop the local seminary into a university. Although in 1763 Maria Theresa refused to authorize a new university, construction works continued, and in 1769 a medical academy was opened. The new observatory tower of Eger was not ready for use until 1776 , but the rudimentary training that Balajthi received during his short stay with Hell, and the full formation as an astronomer given to another student, János Madarassy (1743-1814), sent to Vienna by Eszterházy in 1774, clearly served a grand purpose.

Balajthi's sojourn in Vienna was an occasion for the ambitious and influential prelate and the imperial and royal astronomer to begin a correspondence that lasted, with some intervals, almost until Hell's death. While not a single letter from the bishop seems to have been preserved, those from Hell to him reveal that Eszterházy relied extensively on Hell for obtaining equipment as well as general professional advice. Later on, he would ask Hell to arrange purchases of the best available instruments from England for the new observatory, and even to come to inspect the construction site in Eger in order to give instructions face-to-face. ${ }^{113}$ For the time being, some "mathematical and physical instruments for the public school" were ordered, and while duly reporting first on the financial implications and later on the acquisition of the requested items, Hell never missed the opportunity to reassure the bishop about the dedication and diligence of his student. He also expressed his joy over this occasion to serve his "fatherland" (patria), and promised to make the name of Eszterházy known throughout the world of learning, and to spare no effort in ordering the instruments the bishop asked for. ${ }^{114}$

Unlike Trnava, with its university and astronomical infrastructure under the able governance of Weiss, Eger in the 176 os was certainly not yet in a position to be included in the purview of the Ephemerides, but Hell spared no time and effort in embracing and assisting a local initiative whose aim was to put the

112 László Kádár, “Eszterházy Károly racionalizmusa," Vigilia 64, no. 6 (1999): 443-52, here 443-44. On Eszterházy, see further Béla Kovács, ed., Eszterházy Károly emlékkönyv (Eger: Érseki Gyűjteményi Központ, 1999), especially István Bitskey, "Püspökünk, példánk és tükörünk volt Eszterházy Károly életpályája és egyénisége," 7-22.

113 Hell to Eszterházy in Eger, dated Vienna, November 25, 1774; August 22, 1775; April 23, 1776. FLE, AV, 2629. The same emerges from Madarassy to Eszterházy in Eger, dated Vienna, January 27, 1776; March 3, 1776; April 6, 1776 (Vargha priv.).

114 Hell to Eszterházy in Eger, dated Vienna, August 6, 1762; September 21, 1762; October 24, 1762. Balajthi himself also informed his superior; Balajthi to Eszterházy in Eger, dated Vienna, [September] 21, 1762. FLE, AV, 2629. 
town on the scientific map of the imperial and royal space he officially represented. These efforts needed a good decade to bear some fruit. As yet, those spaces - the second tier of concentric circles around Hell's Vienna-boasted new observatories in Graz, Trnava, and Kremsmünster. ${ }^{115}$ Mid-eighteenthcentury developments at these observatories have already been outlined earlier via the portraits of some of their protagonists: Scherffer, Poda, Weiss, and Fixlmillner, of whom the first three were connected with Hell during his formative years and remained in more or less constant touch with him after his Viennese appointment. Besides them, Joseph Mayr (1720-?), who briefly directed the Graz observatory before Poda, merits attention on account of a single surviving letter by him to Hell, giving an insight into the dynamics within the astronomical community of the Habsburg monarchy.

Little can be ascertained about Mayr, ${ }^{116}$ except that he was born in Passau, entered the Society of Jesus in 1736, studied at the universities of Vienna and Graz, and was appointed as professor of mathematics and prefect of the astronomical observatory in Graz in 1755 (i.e., at around the same time as Hell). Mayr still retained this position when Hell issued the first volume of his Ephemerides, which he personally distributed to colleagues all over the Austrian province and beyond. Mayr was grateful for his copy, and excused himself for the delay in acknowledging it, stressing that

I have used them faithfully in this my worn and all but dilapidated observatory, insofar as it was possible, given my [limited] experience in astronomical matters. If only the fellow who, after the death of pious Vanossius, got the task of delivering two practical lessons every week assigned for himself, back in those days when we as colleagues learned the basics of mathematics, had given us at least some instruction [in astronomy]!117

Recalling the time they spent together completing the philosophy curriculum in Vienna, ${ }^{118}$ Mayr complained to Hell that after the loss of a teacher (whose identity could not be established from the sources), there was no one at hand who might have introduced them to the field he was now supposed to supervise

\footnotetext{
115 Prague, with its traditions going back to Kepler and the astronomical tower in the Clementinum deriving from 1722, is a somewhat separate case. See Zdislav Šíma, Astronomie a Klementinum/Astronomy and Clementinum (Prague: Národní knihovna České republiky, 2006).

116 Fischer, "Jesuiten-Mathematiker in der Deutschen Assistenz," 208.

117 Joseph Mayr to Hell in Vienna, dated Graz, October 17, 1757 (wUs, copy in the hand of Hell's secretary).

118 Mayr was in his second year when Hell began in 1741. Lukács, Catalogi personarum, 8:465.
} 
in Graz. Given that this was just about the time when Hell began his own apprenticeship with Father Franz, the complaint is a strange one, but it also sheds light on the scarcity of available expertise on which the quickly developed astronomical infrastructure of the Austrian province in the 1740 s and 1750 s had to rely: Mayr's lack of training could not have been a secret, but he still got the job. (As we have seen, Fixlmillner on the Benedictine side could be a parallel case - with the difference that Mayr abandoned the field just a few years later.) The gap between the task and his skills seems to have caused him considerable frustration, for he continued:

If only I had been given access to the observatory, either when I followed lectures in theology here in Graz, or when I taught poetry and rhetoric in Vienna! Liesganig, whom I asked quite often [for permission to visit the observatory], always found various pretexts to elude my effort, and in this he followed the example of his patron [presumably, Franz].

Mayr further explained that he wanted to send Hell some occultations, but he had been hesitant because of the unreliability of his observatory's equipment-for which, naturally, his predecessor was to blame:

The observatory is laboring under its own weight, it was constructed to display the looks of an astronomical tower only (in this and the last year it was saved from total ruin to great expense for the collegium), and its instruments were constructed according to the ideas of the instrumentmakers without ever being subjected to professional scrutiny. ${ }^{119}[\ldots]$ The very builder of this device, Halloy, ${ }^{120}$ who at least on his own accord should have been interested to help, I have asked humbly for assistance many times, but each time he ran off and even caused serious trouble.

Eventually, Mayr still decided to send two observations, however deficient they might be, and avowed to being anxious to finally master the field while feeling compelled to abandon it:

I do not hate mathematics, as I am fully aware that this discipline ranks highest among the sciences. Astronomy ought to have been a pleasure to me, but I would have liked to have such helpers that were willing to serve the public good by sharing their advice. Indeed, I would be happy to learn

119 Cf. the sceptical assessments of the performance of the observatory above, 68 .

120 Peter Halloy (1707-89), director of the Graz observatory in $1753-55$. 
from whomsoever, if only I had the chance. Meanwhile, I accept my destiny, and I resort to the same attitude as my predecessors, none of whom were so attached to the observatory in Graz as to prevent them from either seeking immediately to be freed from this burden, or at least congratulating themselves when they were freed from it. I would have loved to accept the name of a colleague that His Reverence [i.e., Hell] gave me so undeservedly, if my contributions had not rendered me totally unworthy of such an honor.

Later in the same year, Mayr indeed left Graz to take up the chair of mathematics in Linz, where he taught until 1760 , before moving to Klagenfurt in $1760-61$ and then Buda in 1761-62. He did not return to teach mathematics at any of the universities proper, and seems not to have pursued astronomy any further. The substance and the tone of his letter to Hell may to a certain extent be ascribed to the resentment and self-victimization of an embittered man, but it sheds light on the supreme need at the time for the kind of systematic and consistent promotion on behalf of astronomy pursued by the imperial and royal astronomer through publications, networking, training, and instrumentation. The first spectacular result of this activity was the part played and the attention received by Hell, his observatory, and its local context during the 1761 Venus transit observations. 